\title{
Structural Basis for the KlenTaq DNA Polymerase Catalysed Incorporation of Alkene- versus Alkyne-Modified Nucleotides
}

\author{
Audrey Hottin, Karin Betz, Kay Diederichs, and Andreas Marx ${ }^{*[a]}$
}

\begin{abstract}
Efficient incorporation of modified nucleotides by DNA polymerases is essential for many cutting-edge biomolecular technologies. The present study compares the acceptance of either alkene- or alkyne-modified nucleotides by KlenTaq DNA polymerase and provides structural insights into how 7-deaza-adenosine and deoxyuridine with attached
\end{abstract}

\section{Introduction}

Nucleobase-functionalized DNA is exploited for many biotechnological applications such as next-generation sequencing with dye-labelled nucleotides, ${ }^{[1,2]}$ the in vitro selection of Iigands such as aptamers by SELEX, for which numerous modifications improve chemical and structural diversity of $\mathrm{DNA}_{1}^{[3]}$ post-synthetic DNA-conjugation, ${ }^{[4]}$ and DNA-microarrays. ${ }^{[5,6]}$ Efficient approaches for the preparation of functionalized oligonucleotides comprise the enzymatic incorporation of modified 2'-deoxyribonucleoside monophosphates (dNMPs) by DNA polymerases through primer extension (PEX) or polymerase chain reaction $(P C R) .{ }^{[7,8]}$ Therefore, it is essential that the modification attached to the nucleotide does not significantly compromise enzyme activity. During the last years, constant efforts have been made to identify modified triphosphates ( $d N^{R} T P s$ ) that are well processed by DNA polymerases. ${ }^{[9-13]}$ Thereby nucleobase modifications are mainly attached at the $C 5$ position of pyrimidines and the C7 position of 7-deazapurines (Figure $1 \mathrm{~A}$ ) to direct the modifications pointing into the developing major groove of the DNA. ${ }^{[14-16]}$ Larger functionalities are often connected to the nucleobase via linkers that vary in composition, length and flexibility. With this strategy a variety of probes, even very bulky ones, could be incorporated into DNA oligonucleotides. ${ }^{[17-22]}$ Functional studies revealed that the success of efficient incorporation of a specific modified substrate by a DNA polymerase depends amongst others on the nucleobase and the attachment position, ${ }^{[23,24]}$ the linker type, ${ }^{[25]}$ the modification coupled and the polymerase used. ${ }^{[26]}$ Recently, there were even some dNTP analogues identified

[a] Dr. A. Hottin, Dr. K. Betz, Prof. Dr. K. Diederichs, Prof. Dr. A. Marx Department of Chemistry and Department of Biology

University of Konstanz, Universitätsstrasse 10, 78457 Konstanz (Germany)

Email:andreas.marx@uni konstanz.de alkene-modifications are incorporated into the growing DNA strand. Thereby, we identified modified nucleotides that prove to be superior substrates for KlenTaq DNA polymerase compared with their natural analogues. The knowledge can be used to guide future design of functionalized nucleotide building blocks.

A)

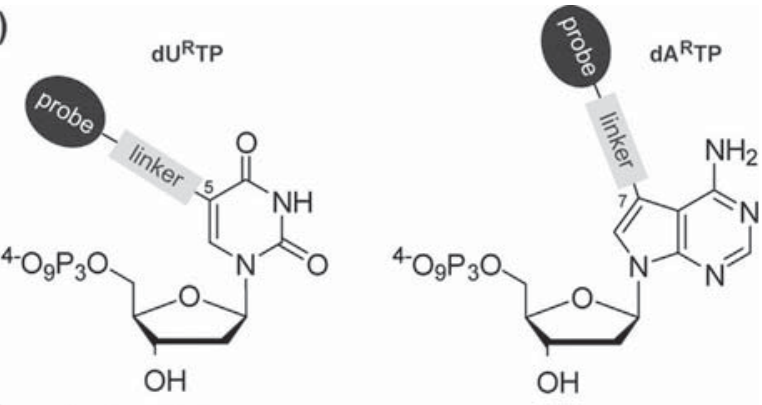

B) previously studied

PDB IDs<smiles>CCC#Cc1ccc(C)cc1</smiles>

C) this study<smiles>CC=CCCCNC(=O)C(C)(O)O</smiles><smiles>CC#CCCCNC(=O)C(C)O</smiles>

Figure 1. A) General design of modified nucleotide substrates based on dUTP and 7 deaza dATP. B) Structure of the linkers (or parts of them) that were structurally characterised in the active site of KlenTaq DNA polymerase in our group with the respective PDB codes of the complexes. C) Structures of the linkers investigated in this study attached to either dUTP or 7 deaza dATP.

that are better substrates for DNA polymerases than their natural counterparts. ${ }^{[27-29]}$

To better understand the acceptance of nucleobase-modified substrates by DNA polymerases, structural studies were performed in our group (reviewed in ref. [30]). We solved the crystal structures of KlenTaq DNA polymerase (large fragment of Thermus aquaticus DNA polymerase I) in complex with nucleotides that carry different functionalities attached to the nucleobase through alkyne linkers (Figure 1B). Thereby, interaction patterns were identified that can enable the enzyme to 
tolerate the modifications. In detail, one study suggests that the introduction of an aromatic ring in a rigid, nonpolar alkyne linker can improve the processing by newly formed cation- $\pi$ interactions with positively charged amino acid side chains. ${ }^{[31,32]}$ Other structures with derivatives harbouring more flexible modifications such as branched polyamide or aminopentynyl moieties highlight the beneficial effects of including functionalities with hydrogen-bonding capability that can stabilise the enzyme-substrate complex. ${ }^{[28,33]}$ Rigid and bulky modifications with little capability to perform stabilising interactions with the protein, however, lead to low incorporation efficiency, probably due to enzyme-substrate complex perturbation. ${ }^{[3]}$ These results already provide first guidelines to tweak incorporation efficiency when designing nucleotides for specific applications. The described structural studies were solely performed with alkyne-modified nucleotides, and the expansion to other linkage types is desirable.

Besides alkyne linkers, alkene linkage to the nucleobase is also frequently used, and the modified nucleotides have proven to be good substrates in PEX and PCR.$^{[12,25,34,35]}$ In addition, alkene linkers present spectroscopic properties that can be of interest for electrochemical studies as redox labels. ${ }^{[36]}$ Direct comparison of these two linkage types with the same modification are only sparsely reported. In a study by Lee et al., different linker types attached to 2'-deoxyuridine triphosphates were evaluated and more rigid $E$-alkene and alkyne linkers turned out to be preferable compared with Z-alkenes or highly flexible alkane linkers. ${ }^{[25]}$ Moreover, modified 2'-deoxyuridine triphosphates with $E$-alkenyl linkers performed better in generation of longer DNA products than substrates with the same modifications attached through alkyne linkers. Although there was no significant difference in incorporation efficiency using alkynyl-, Z-alkenyl- or alkyl-linkers attached to 7-deaza-2'deoxyadenosine triphosphates. ${ }^{[35]}$

Given that alkene linkers have not yet been explored on a structural basis, we aimed to expand our previous studies with KlenTaq DNA polymerase to gain further insights into the interplay of enzyme and substrate. Here, we chose to investigate the performance of alkene-modified nucleotides with the triphosphates $\mathbf{d} \mathbf{U}^{\text {ene }} \mathrm{TP}$ and $\mathbf{d A} \mathrm{A}^{\text {ene }} \mathrm{TP}$ bearing a $5-\mathrm{N}$-(10-hydroxydecanoyl)aminopentenyl modification that is tailored for example, for dye labelling of DNA (Figure 1C). To probe the impact of the modification chemistry on DNA polymerase substrate scope, the alkene derivatives were compared to their alkyne counterparts (d $\left.\mathbf{U}^{\mathrm{kyn}} \mathrm{TP}, \mathbf{d} \mathbf{A}^{\mathrm{kyn}} \mathrm{TP}\right)$ by competitive incorporation experiments with the respective natural substrates as well as by structural means.

\section{Results and Discussion}

\section{Synthesis of the alkene-modified triphosphate $\mathrm{dU}^{\text {ene }} \mathrm{TP}$}

The alkene linker was introduced by palladium-catalysed Heck cross-coupling from the unprotected halogenated nucleoside 5-iodo 2'-deoxyuridine $\mathbf{1}$ with trifluoropentene acetamide (Scheme 1). ${ }^{[37]}$ The reaction catalysed by palladium(II) acetate in the presence of triphenylphosphine as ligand and triethyl-
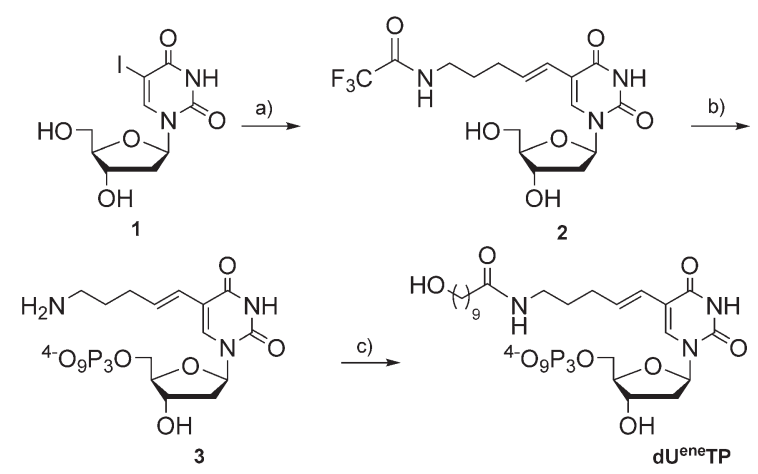

Scheme 1. Synthesis of modified triphosphate dU ${ }^{\text {ene }}$ TP. Reagents and condi tions: a) $\mathrm{Pd}(\mathrm{OAc})_{2}, \mathrm{PPh}_{3}, \mathrm{Et}_{3} \mathrm{~N}, 2,2,2$ trifluoro $\mathrm{N}$ (pent 4 enyl)acetamide, $\mathrm{DMF}$, $100^{\circ} \mathrm{C}, 1 \mathrm{~h}$; b) proton sponge, $\mathrm{POCl}_{3}, \mathrm{PO}(\mathrm{OMe})_{3}, 0^{\circ} \mathrm{C}$, then $\left(\mathrm{Bu}_{3} \mathrm{NH}\right)_{2} \mathrm{H}_{2} \mathrm{P}_{2} \mathrm{O}_{7}$, $n \mathrm{Bu}_{3} \mathrm{~N}, 0.1 \mathrm{M}$ TEAB buffer, ammonium hydroxide; c) succinimidyl 10 hydroxy decanoate, $0.1 \mathrm{~m}$ sodium carbonate buffer ( $\mathrm{pH} 8.7$ ), DMF, $2 \mathrm{~h}, \mathrm{RT}$.

amine as base, led to the desired trans-nucleoside 2 in 14\% yield after purification. The low reactivity can be explained by the use of a non-activated alkene for this reaction. Thereupon, nucleoside $\mathbf{2}$ was converted into uridine triphosphate analogue 3 by using an optimised Yoshikawa phosphorylation procedure. ${ }^{[38]}$ By subsequent coupling of $\mathbf{3}$, bearing an aminolinker, with an NHS-activated acid to form the amide bond, triphosphate $\mathbf{d U}^{\text {ene }} \mathbf{T P}$ was obtained.

\section{Synthesis of the alkene-modified triphosphate $d A^{\text {ene } T P}$}

For the adenosine derivative, the palladium-catalysed Heck cross-coupling from 7-deaza 2'-deoxy-7-iodoadenosine only led to degraded material. Thus, we developed a two-stage strategy for the formation of the alkene modification by first introducing a vinyl group at position C7 of the purine by Stille cross-coupling ${ }^{[39]}$ and then by performing a cross-metathesis of that terminal alkene with a terminal olefin of interest (Scheme 2). ${ }^{[40]}$ In detail, iodoadenosine 4 reacted with tributyl(vinyl)tin using $\mathrm{Pd}\left(\mathrm{PPh}_{3}\right)_{4}$ as catalyst giving 7-vinyl substituted nucleoside $\mathbf{5}$ in high yield. Before metathesis, compound $\mathbf{5}$ was protected with benzoyl groups due to possible Ru-catalyst poisoning by the exocyclic amine. The cross metathesis between adenosine 6 and pentenyltrifluoroacetamide was performed in toluene in the presence of Grubbs II catalyst, ${ }^{[41]}$ leading to a mixture of diastereoisomers ( $E / Z$ ratio $3: 1)$. Further deprotection of benzoylated derivative $7 E / Z$ using $7 \mathrm{~N} \mathrm{NH}_{3}$ in methanol gave nucleoside $8 E / Z$ as an $E / Z$ mixture and compound $9 E / Z$, which was easily recycled through its protection with a trifluoroacetyl group. Combined fractions of $\mathbf{8 E / Z}$ were then purified by preparative HPLC to isolate the trans-alkene nucleoside. The triphosphorylation of $\mathbf{8 E}$ and the subsequent coupling with an NHS-activated acid provided the desired nucleotide $d A^{\text {ene }}$ TP. Triphosphates $d U^{k y n} T P$ and $d A^{k y n} T P$ were synthesised as previously described. ${ }^{[6,28]}$

\section{Primer extension studies}

First, we investigated the acceptance of the four 2'-deoxyribonucleoside triphosphates $\mathbf{d N}^{\mathrm{R}} \mathrm{TPs}$ in DNA polymerase catalysed 

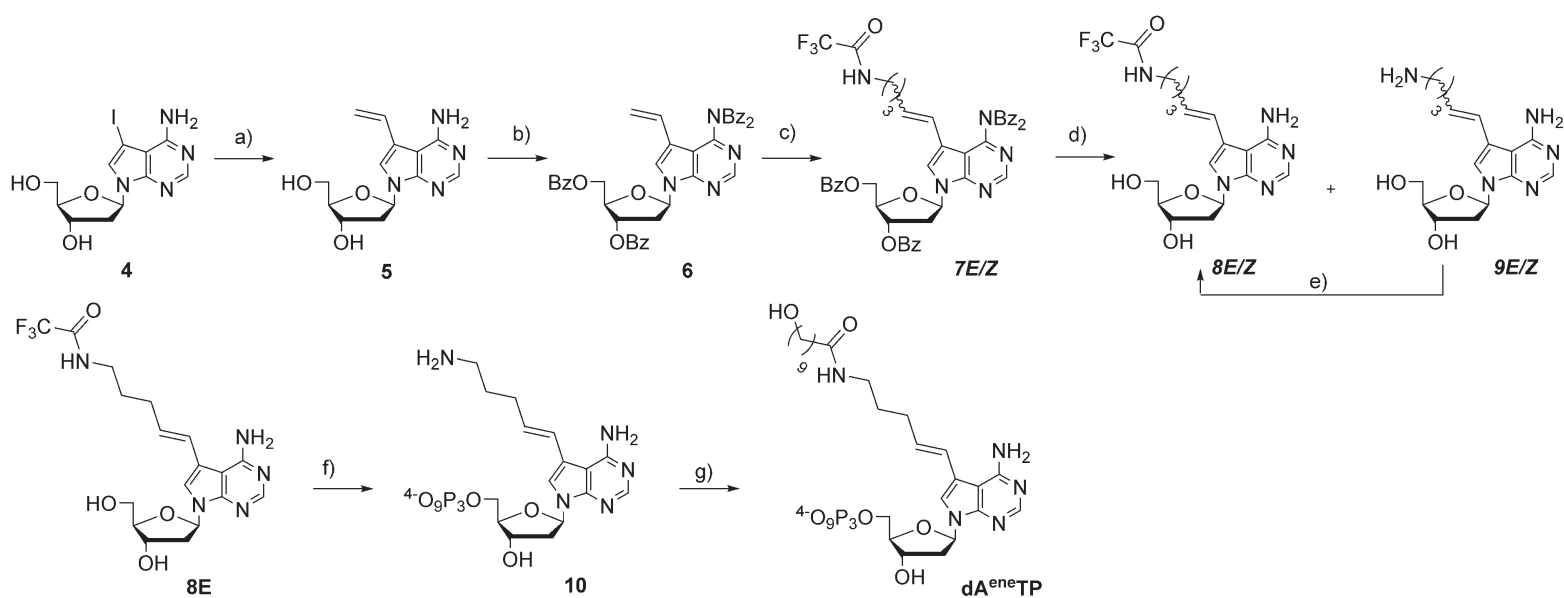

Scheme 2. Synthesis of 2 ' deoxyadenosine analogue $\mathrm{dA}^{\text {ene }} \mathrm{TP}$. Reagents and conditions: a) tributyl(vinyl)tin, $\left.\mathrm{Pd}\left(\mathrm{PPh}_{3}\right)_{4}, \mathrm{DMF}, 100{ }^{\circ} \mathrm{C}, 2 \mathrm{~h} ; \mathrm{b}\right) \mathrm{BzCl}, \mathrm{pyr}, \mathrm{RT}, 2 \mathrm{~h}$; $83 \%$; c) pentenyltrifluoroacetamide, Grubbs Il, toluene, $100^{\circ} \mathrm{C}, 2 \mathrm{~h}$; d) $7 \mathrm{~N} \mathrm{NH}_{3}$ in $\mathrm{MeOH}, 50^{\circ} \mathrm{C}$, overnight; e) $\mathrm{CF}_{3} \mathrm{COOEt} \mathrm{DMAP}, \mathrm{THF}, 90^{\circ} \mathrm{C}, 4 \mathrm{~h}$; f) proton sponge, $\mathrm{POCl}_{3}, \mathrm{PO}(\mathrm{OMe})_{3}, 0^{\circ} \mathrm{C}$, then $\left(\mathrm{Bu}_{3} \mathrm{NH}\right)_{2} \mathrm{H}_{2} \mathrm{P}_{2} \mathrm{O}_{7}, n \mathrm{Bu}_{3} \mathrm{~N}, 0.1 \mathrm{M}$ TEAB buffer, ammonium hydroxide; g) succinimidyl 10 hydroxydecanoate, $0.1 \mathrm{M}$ sodium car bonate buffer (pH 8.7), DMF, $2 \mathrm{~h}, \mathrm{RT}$.

primer extension reaction. By using a ${ }^{32} \mathrm{P}$-labeled 22-mer primer and a 36-mer template, each modified $\mathbf{d N}^{\mathrm{R}} \mathrm{TP}$ was incubated with KlenTaq DNA polymerase in the presence of the other three natural nucleotides. After four minutes, the fulllength product was obtained in all cases, clearly showing the ability of the DNA polymerase to use these modified nucleotides as substrates (Figure S1). To investigate the incorporation efficiency of modified versus natural substrate, we performed single nucleotide incorporation experiments in which the modified nucleotide competes directly with its natural counterpart. This setup was previously used for the same purpose ${ }^{[33]}$ as well as to study DNA polymerase selectivity. ${ }^{[42]}$ The relative incorporation of natural nucleotide versus modified nucleotide was monitored by denaturing polyacrylamide gel electrophoresis (PAGE) and phosphorimaging, taking advantage of the significantly different migration of naturally extended primer compared with modified extended primer due to the bulky modification (Figure 2B). Competition experiments for analogues $\mathbf{d} \mathbf{U}^{\mathrm{kyn}} \mathrm{TP}$ and $\mathbf{d} \mathbf{A}^{\mathrm{kyn}} \mathrm{TP}$ have been published before, ${ }^{[28]}$ but were repeated under the same conditions (incubation time, enzyme batch and concentration) as for $\mathbf{d U}^{\text {ene }} \mathbf{T P}$ and $d A^{\text {ene }}$ TP. The results for all four nucleotides are summarised in Figure $2 \mathrm{~A}$. The competition experiments identified three candidates that proved to be superior substrates for KlenTaq DNA polymerase compared with their natural analogues, namely $\mathbf{d U}^{\text {ene }} \mathbf{T P}, \mathbf{d} \mathbf{A}^{\text {ene }} \mathbf{T P}$ and $\mathbf{d A}^{\mathrm{kyn}} \mathbf{T P}$. The adenosine derivatives

A)

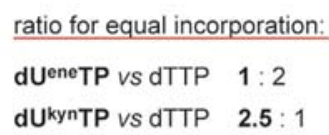

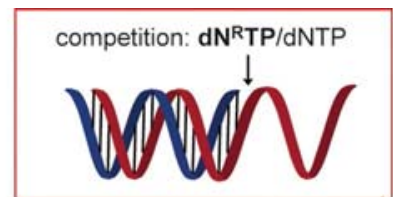

ratio for equal incorporation:

dA ene TP vs dATP $1: 4.6$

dAkynTP vs dATP $\quad \mathbf{1}: 4.3$

B)
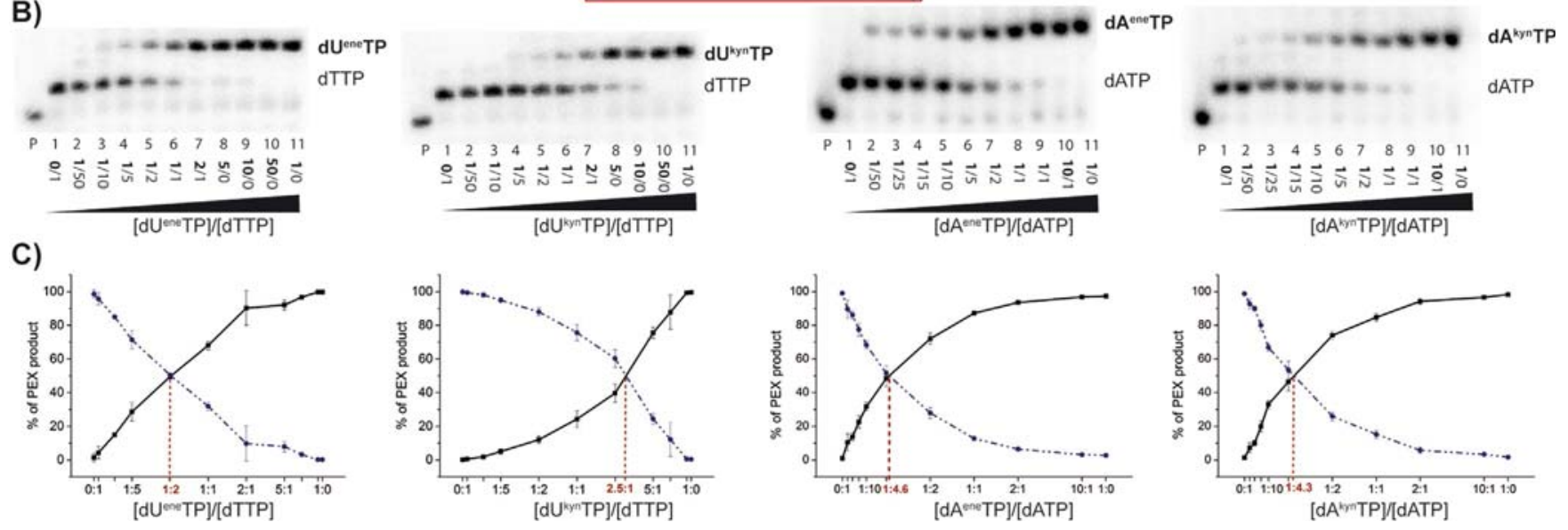

Figure 2. A) Ratio $d^{R} N^{R}$ P versus dNTP when both nucleotides are equally incorporated by KlenTaq DNA polymerase. B) PAGE analysis of the competition ex periments with various ratios of $\mathbf{d N}^{\mathrm{R}} \mathrm{TP}$ versus dNTP. Lane P: $5^{\prime}{ }^{32} \mathrm{P}$ labelled primer; lane 111 different ratios of $\mathbf{d N}{ }^{\mathrm{R}} \mathrm{TP} / \mathrm{dNTP}$. C) Quantification of the PAGE analysis. The point of equal incorporation is indicated by a red dashed line. 
$d A^{\text {ene }}$ TP and $d A^{k y n} T P$ display similar incorporation efficiencies, with 4-fold excess of dATP concentration required to obtain an equal ratio of primer extended by dATP and $\mathbf{d A}^{\mathrm{R}} \mathrm{TP}$. KlenTaq incorporated the alkene-modified uridine nucleotide $\mathbf{d U}^{\text {ene }} \mathrm{TP}$ and dTTP equally when a 2-fold excess of dTTP was used. However, its alkyne counterpart dU ${ }^{k y n} T P$ was a poorer substrate than dTTP for KlenTaq DNA polymerase. ${ }^{[28]}$

\section{Structural studies}

The interesting results from the incorporation studies prompted us to solve crystal structures of KlenTaq DNA polymerase in complex with $\mathbf{d U}^{\text {ene }} \mathrm{TP}$ and $\mathbf{d A} \mathrm{A}^{\text {ene }}$ TP bound in the active site and to compare them with a natural substrate as well as with the already available data of KlenTaq DNA polymerase with $\mathbf{d U}^{\mathrm{kyn}}$ TP and $\mathbf{d} \mathrm{A}^{\mathrm{kyn}}$ TP bound (PDB IDs 4DFK and 4DF4 ${ }^{[28]}$ ). The primer contained a ddC at the $3^{\prime}$-end to capture the incoming modified $\mathbf{d N}^{\text {ene }} \mathbf{T P}$ at the insertion site, yielding a structural snapshot just before the imminent incorporation reaction. Ternary complexes, consisting of polymerase, primer/template and the $\mathbf{d N}^{\text {ene }} \mathbf{T P s}$, were obtained by co-crystallisation. Crystals exhibit the same space group $\left(\mathrm{P}_{1} 2_{2}, 2\right)$ and similar cell dimensions as the previously solved KlenTaq DNA polymerase structures. The structures were refined using data to a resolution of $1.8 \AA$ (for data collection and refinement statistics see Table S1).

\section{Ternary complex with dU ${ }^{\text {ene }} \mathrm{TP}$}

The overall structure of KlenTaq(dU $\left.{ }^{\text {ene }} \mathbf{T P}\right)$ is similar to KlenTaq DNA polymerase in complex with a ddTTP substrate (PDB ID: 1 QTM, core root-mean-square deviation (rmsd): $0.36 \AA)^{[43]}$ or to the more recently published structure with the natural substrate dCTP bound (PDB ID: $3 \mathrm{RTV}^{[44]}$ core rmsd: $0.26 \AA$ Figure $2 \mathrm{~B}$ ), which is referred to as KlenTaq(dCTP) in this paper. The polymerase adopts a closed conformation with the O-helix (part of the finger domain, residues 657-671) covering the nascent $d A-d U^{\text {ene }}$ TP base pair. The linker does not disturb the complex and usual binding interactions of the substrate, such as canonical Watson-Crick base-pairing to the template or $\pi$ stacking with the primer strand, as well as $\mathrm{H}$-bonds of the $\alpha$ and $\gamma$ phosphate with Lys663 are maintained (Figure 3A,D). Residues in the catalytic site are oriented as observed in KlenTaq(dCTP). The complex is trapped in a state prior to the incorporation reaction in which the two catalytic magnesium ions are coordinated by the side chains of Asp610, Asp785, the backbone of Tyr611, the phosphate groups of $\mathbf{d U}^{\text {ene }} \mathbf{T P}$ and two water molecules (Figure 2D,E). The distance of the $\alpha$-phosphate of the substrate to the nucleophilic 3'-primer end (for distance measurement the ribose $C 3$ is used) is virtually identical to the natural complex (3.8 $\AA$ vs. $3.9 \AA$ ). The $\mathbf{d U} \mathbf{U}^{\text {ene }}$ TP sugar, base and triphosphate moieties are well resolved and electron density for the linker is unambiguous up to the amide functionality (Figure $3 \mathrm{~A}$ and Figure S2A, B). The remaining linker could not be traced and was refined with zero occupancy. The linker extends from the C5-position of $\mathbf{d U}^{\text {ene }} \mathrm{TP}$ through
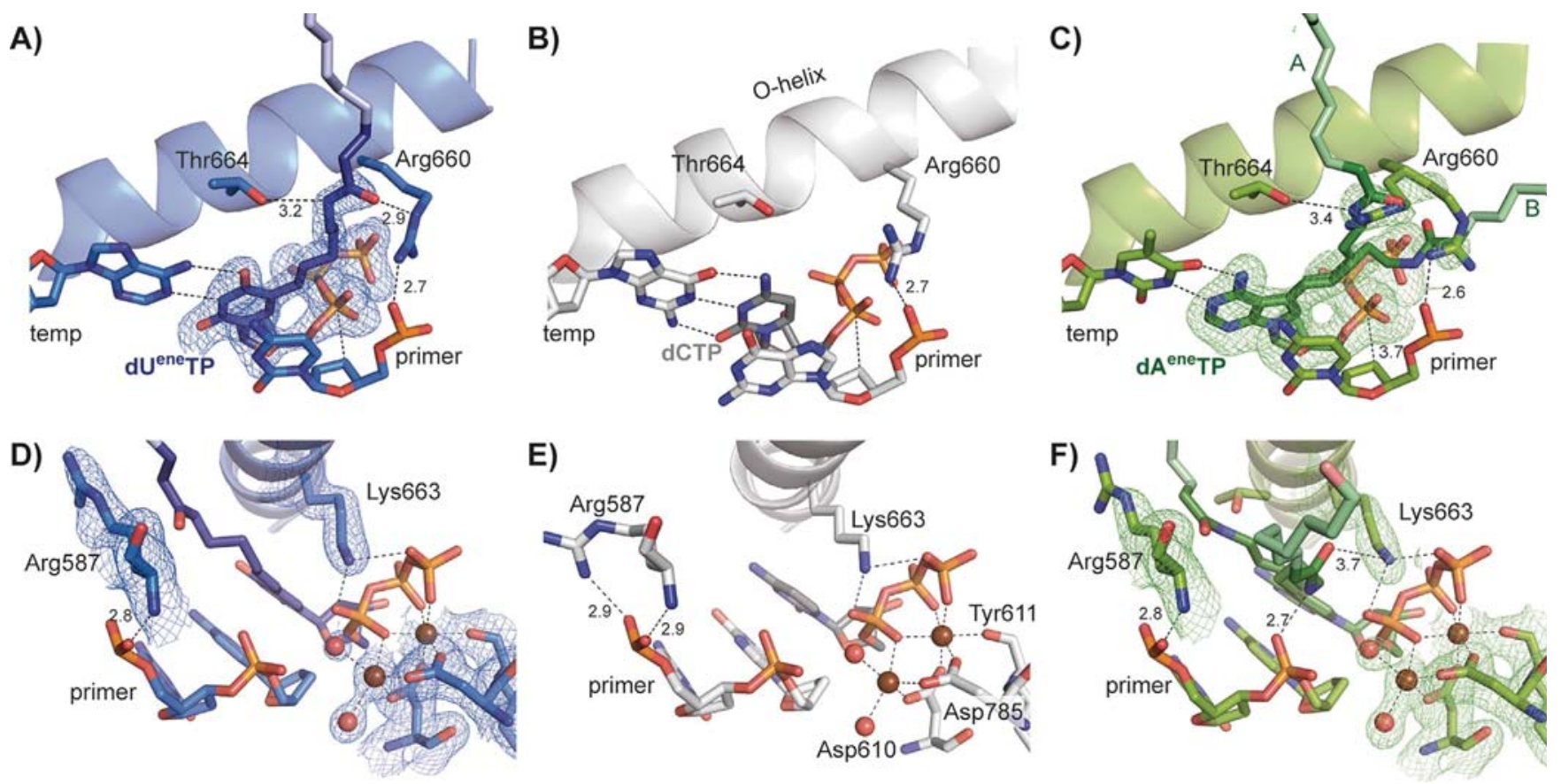

Figure 3. Structure of KlenTaq DNA polymerase in complex with $\mathbf{d N}^{\mathrm{R}} \mathrm{TP}$. The dashed lines highlight the interaction pattern described in the text. All distances are given in A.. A C) Detailed view on the insertion site of KlenTaq(dU ${ }^{\text {ene }}$ TP), blue; KlenTaq(dCTP), grey and KlenTaq(dA ${ }^{\text {ene }}$ TP), green. The substrate and near protein and primer/template residues are shown as sticks and the $\mathrm{O}$ helix is shown as cartoon. The linker portion refined with zero occupancy is displayed in lighter colour. $\mathbf{d U}^{\text {ene }} \mathrm{TP}$ and $\mathbf{d} \mathbf{A}^{\text {ene }} \mathrm{TP}$ are surrounded by omit maps contoured at $2.5 \sigma$. The modification of $d A^{\text {ene }}$ TP leaves the enzyme in two different confor mations, which are labelled with A and B. D F) View on the respective catalytic sites of the three structures. Magnesium ions and water molecules are shown as brown and red spheres, respectively. 2 mFo DFc map $(1 \sigma)$ is shown for interacting protein residues. 

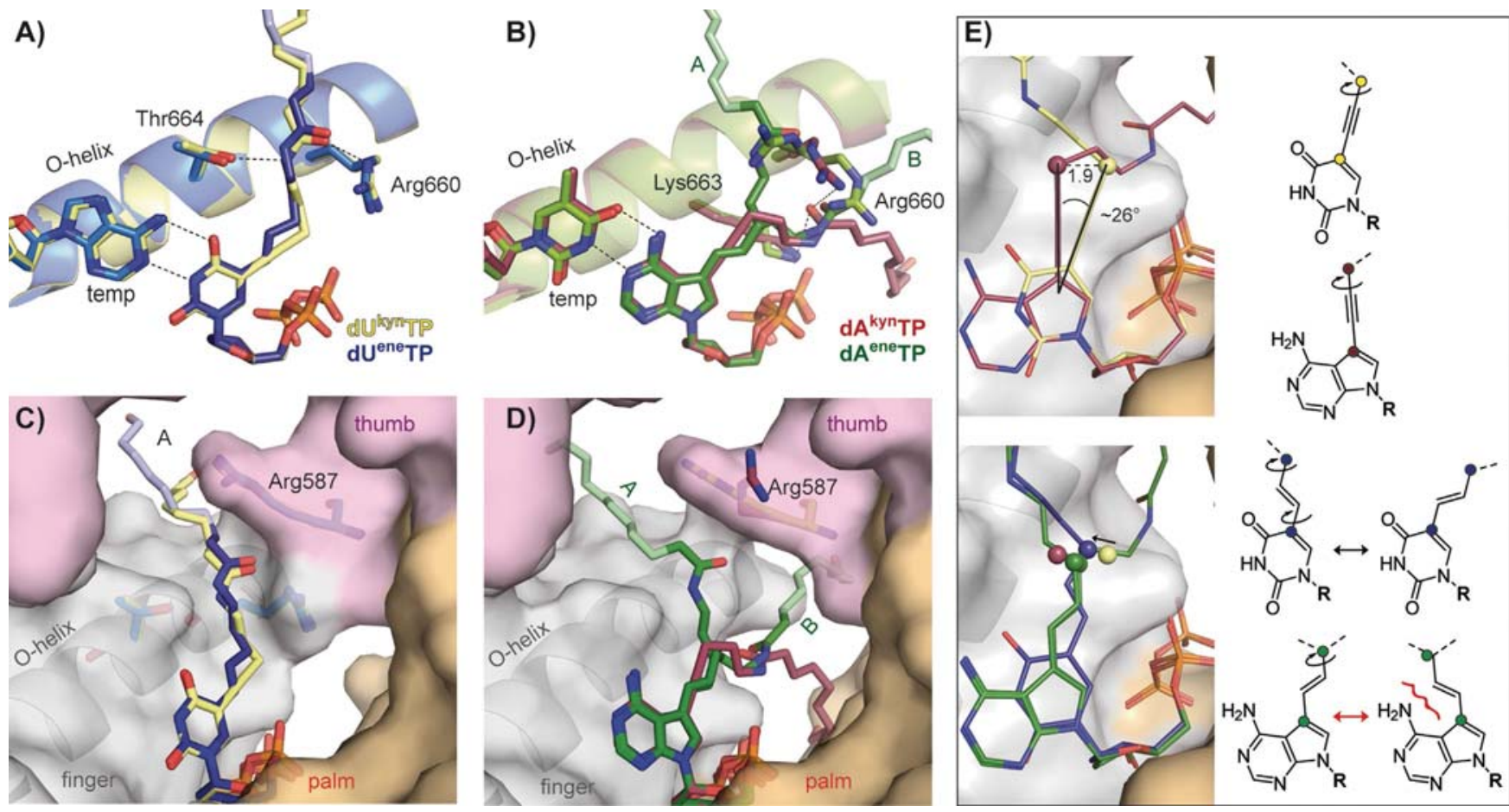

Figure 4. Comparison of alkyne or alkene modified nucleotides bound in the active site of KlenTaq DNA polymerase. A) Same arrangement as in Figure $3 \mathrm{~A}$

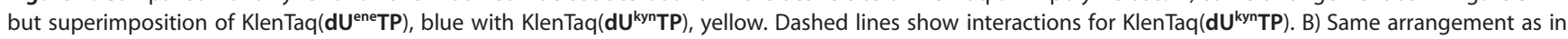
Figure $3 C$ but superimposition of $\operatorname{KlenTaq}\left(\mathbf{d} A^{\text {ene }} \mathbf{T P}\right)$, green with KlenTaq(dA $\left.A^{\mathrm{kyn}} \mathrm{TP}\right)$, red. C,D) Cavities $A$ and $B$ through which the modifications pass the enzyme. The surface of KlenTaq(dA ${ }^{\text {ene }} \mathbf{T P}$ ) is shown (Arg660 omitted) with the thumb, finger and palm domain coloured pink, grey and orange, respectively. E) Superimposition of $\mathbf{d} \mathbf{U}^{\mathrm{R}} \mathrm{TPs}$ and $\mathbf{d} \mathbf{A}^{\mathrm{R}} \mathrm{TPs}$ in the crystal structures and schematic view on the respective rotation points (displayed as coloured spheres) for alkyne or alkene modifications. The potential clash for $\mathbf{d A}{ }^{\text {ene }}$ TP when rotating around the $\mathrm{C} 7$ linker bond is indicated in red.

a cavity between the finger and thumb domain (denoted cavity A), mainly bordered by the Arg587 side chain and residues from the O-helix as was already observed in KlenTaq(dU $^{\text {kyn }}$ TP) (Figure 4A,C). The two amino acids Arg660 and Arg587 show different conformations compared with the natural case KlenTaq(dCTP) (Figure 3B,E). Although Arg660 is slightly displaced to make space for the modification, it can still maintain its interaction with the primer 3 '-end in the closed ternary complex (Figure $3 \mathrm{~A}$ ). The side chain of Arg587 is now oriented along the linker and thereby loses its interaction with the primer backbone. The interaction of the Arg587 main chain with the backbone, however, is maintained (Figure 3D). The $\mathbf{d U}^{\text {ene }} \mathbf{T P}$ linker itself is capable of engaging two specific interactions to adjacent $\mathrm{O}$-helix residues through its amide functionality: one with the guanidinium group of the already mentioned Arg660 and a second with the side chain of Thr664 (Figure $3 \mathrm{~A}$ ). We assume that these interactions may well stabilise the linker-bearing substrate and contribute to the proficient processing of this analogue by KlenTaq DNA polymerase. Identical enzyme-substrate interactions are observed in the previously solved structure of alkyne modified $\mathbf{d} \mathbf{U}^{\mathrm{kyn}} \mathrm{TP}$, in which the linker protrudes from the enzyme through the same cavity (Figure 4A,C). However, this nucleotide is less well processed by KlenTaq DNA polymerase than dTTP in our assay. Therefore, other differences between unmodified, dU-alkene- or dUalkyne-modified nucleotides must occur in the process of substrate binding, active complex formation, catalytic reaction, and/or substrate release that result in the difference of processing.

\section{Ternary complex with $d A^{\text {ene }}$ TP}

KlenTaq(dA $\left.{ }^{\text {ene }} \mathbf{T P}\right)$ was also obtained as a closed active complex, and the overall structure is again almost identical to the unmodified case KlenTaq(dCTP) (Figure 3C, F; core rmsd: $0.40 \AA$ ). The distance of the $\alpha$-phosphate of the substrate to the nucleophilic 3'-primer end is $3.7 \AA$ ( $3.9 \AA$ in the natural complex). In contrast to $\mathrm{KlenTaq}\left(\mathbf{d} \mathbf{U}^{\text {ene }} \mathbf{T P}\right)$, it appears that the modification of $\mathbf{d A}{ }^{\text {ene }}$ TP can take two different orientations to exit the enzyme. The relatively weak electron density of the linker portion and the near Arg660 side chain indicated flexibility and was initially difficult to interpret. The best solution was to model alternative conformations of the ligand with the linker pointing in two different directions as well as two conformations of the Arg660 side chain (Figure 3C,F and Figure 4B,D). For modelling, we made use of polder and omit maps generated with the program Phenix ${ }^{[45]}$ (Figure S3 C,D). The alternative conformations of Arg660 and the ligand including triphosphate, sugar, nucleobase and linker up to the amide functionality were refined with an occupancy of 0.5 . The rest of the linker, which was not visible in the electron density, was modelled as an extension to the more rigid part and refined with zero occupancy. In conformation one, the modification extends to the surface of the enzyme through cavity A, as already 
noted with $\mathbf{d U}^{\text {ene }} \mathbf{T P}$ and $\mathbf{d} \mathbf{U}^{\mathrm{kyn}} \mathbf{T P}$. Here again, the enzyme substrate complex may be stabilised by Thr664 through interaction with the amide present on the linker (Figure $3 \mathrm{C}$ ). In contrast to the natural case, Arg587 is again oriented along the linker but maintains its backbone interaction with the primer (Figure 3F). In the second conformation the modification runs parallel to the O-helix and passes through another cavity (cavity B) mainly formed by the palm and finger domains (Figure 4D). This orientation has already been observed in the previously solved structure of KlenTaq(dA $\left.{ }^{\text {kyn }} \mathbf{T P}\right){ }^{[28]}$ In this conformation, Lys663 can interact with the amide bond (as is the case in $\operatorname{KlenTaq}\left(\mathbf{d} A^{\mathrm{kyn}} \mathrm{TP}\right)$ ), however the distance of $3.7 \AA$ is too long for a $\mathrm{H}$-bond. The presence of two conformations of Arg660 and the resulting weakly defined electron density means that it is hard to judge whether the modelled conformations display the actual situation of that residue and therefore we can only speculate on interactions it may engage. However, it is well possible that Arg660 interacts with the primer backbone (as in KlenTaq(dU $\left.{ }^{\text {ene }} \mathbf{T P}\right), \operatorname{KlenTaq}\left(\mathbf{d} \mathbf{U}^{\mathrm{kyn}} \mathbf{T P}\right)$ and KlenTaq(dCTP)) when the modification points to cavity A (Figure 3 C). When the modification occupies cavity B, Arg660 is probably too far displaced from the primer backbone. In this situation, interaction of the amide moiety of the substrate with the phosphate group of the primer terminus is possible, which can compensate the "lost" interaction of Arg660 with the primer terminus. This interaction with the primer is also possible in KlenTaq $\left(\mathbf{d} \mathbf{A}^{\mathrm{kyn}} \mathrm{TP}\right.$ ) (although this is not mentioned in the publication ${ }^{[28]}$ ).

In contrast to the alkene or alkyne modification attached to uridine we do not observe a difference in incorporation efficiency when attached to 7-deaza-adenosine. Both adenosinemodified nucleotides are to the same rate better incorporated than dAMP, although they show differences in the structure. Whereas in KlenTaq (dA $\left.A^{\text {kyn }} \mathrm{TP}\right)$ the linker follows only one direction (direction $B$ ) it can adopt two different conformations for $d A^{\text {ene }}$ TP. Both conformations show additional interactions with the enzyme or primer backbone and the substrate amide moiety, emphasising the importance of this moiety within the linker portion as discussed previously. ${ }^{[28]}$ The different linkage type (alkene vs. alkyne) does not make a difference with the linker investigated here but may influence incorporation efficiency when sterically more demanding groups are attached. The knowledge that both modification types are equally well accepted when linked to 7-deaza-adenosine enlarges the repertoire from which to choose when designing modified nucleotides for a specific application.

\section{Comparison of $d U^{R} T P s$ and $d A^{R} T P s$}

As just discussed, the linkage type does not change incorporation efficiency whether the 5- $\mathrm{N}$-(10-hydroxydecanoyl)-aminopentenyl- or the 5-N-(10-hydroxydecanoyl)-aminopentynylmodification is attached to 7-deaza-dATP. When attached to dUTP, however, different linkage type results in different incorporation behaviour for dU ${ }^{\text {ene }}$ TP and $\mathbf{d U}^{\mathrm{kyn}} \mathrm{TP}$ by KlenTaq DNA polymerase. The same tendency has been observed by Williams and co-workers. ${ }^{[25,35]}$ The crystal structures solved in this and previous work cannot explain the difference between $d^{R} T P s$ and $d A^{R} T P s$ because neither of the modifications disturbs the enzyme to form an active closed complex and, in both cases, potentially stabilising interactions of the linker with the enzyme or primer are possible. However, the presented crystal structures only represent a single snapshot of the whole insertion reaction; namely, the step after binding of the substrate and closure of the finger domain. Therefore, we assume that differences arise in a different step in the insertion process, for example during substrate binding, enzyme closure, the actual chemical reaction or substrate release. What can nicely be seen in the structures is that the angle by which the rigid part of the alkyne linker protrudes from the nucleobases when base-pairing in the active site differs by approximately $26^{\circ}$ (Figure 4E). This results in different positions of the points from where the $C \mathrm{C}$ bonds can rotate and the modification gets flexible (distance 1.9 $\AA$ ). With alkene linkers this difference is reduced because of the additional kink resulting from the double bond. For $\mathbf{d} \mathbf{U}^{\text {ene }} \mathrm{TP}$ compared with $\mathbf{d U ^ { k y n }} \mathrm{TP}$, the point of rotation shifts towards the templating nucleotide and away from the triphosphate moiety (arrow in Figure 4E). This different position might be more favourable somewhere in the reaction cascade. Another point that can be noted is that alkene linkers attached to dUTP have additional flexibility compared with the alkyne linkers, as rotation around the bond at C5 leads to different positioning of the double bond and the rest of the linker. For 7-deaza-dATP, this rotation seems less favourable because of a clash between the free amine of 7-deaza-adenine and a hydrogen of the alkene moiety. In some way, these differences may lead to the fact that both $d A^{R} T P s$ are better substrates than dATP but only d $\mathbf{d U}^{\text {ene }}$ TP and not dU ${ }^{\mathrm{kyn}} \mathrm{TP}$ is preferably incorporated over dTTP.

\section{Conclusions}

In this work two modified nucleotides were synthesised and evaluated towards their acceptance by KlenTaq DNA polymerase. We show by a competitive incorporation assay that the two alkene derivatives $\mathbf{d} \mathbf{A}^{\text {ene }} \mathbf{T P}$ and $\mathbf{d} \mathbf{U}^{\text {ene }} \mathbf{T P}$ are excellent substrates for KlenTaq DNA polymerase, displaying even better substrate properties than the respective natural analogues. In addition, the proficient incorporation of $d A^{k y n} M P$ over dAMP from a previous study was confirmed. The presented ternary structures $\operatorname{KlenTaq}\left(\mathbf{d} \mathbf{A}^{\text {ene }} \mathbf{T P}\right)$ and $\operatorname{KlenTaq}\left(\mathbf{d} \mathbf{U}^{\text {ene }} \mathbf{T P}\right)$ support this observation, as in analogy to the previously solved structures $\operatorname{KlenTaq}\left(\mathbf{d} \mathbf{U}^{\mathrm{kyn}} \mathrm{TP}\right)$ and $\operatorname{KlenTaq}\left(\mathbf{d} \mathbf{A}^{\mathrm{kyn}} \mathrm{TP}\right)$ the modifications do not disturb formation of a catalytic complex. We observe a full closure of the enzymes finger domain and proper interaction of the substrate triphosphate within the active site. The modifications point into directions where they can leave the enzyme through two different cavities. Interactions of the protein or the primer backbone with the amide moiety of the linker may stabilise the ternary complex in both possible directions and support the proficient incorporation behaviour of $d A^{k y n} T P$, $\mathbf{d A}^{\text {ene }} \mathbf{T P}$ and $\mathbf{d U ^ { \text { ene } }}$ TP. No obvious mechanism why $\mathbf{d U ^ { k y n }} T \mathbf{P}$ is less well processed than $\mathbf{d U}^{\text {ene }} \mathrm{TP}$, however, could be deduced from the obtained structure. The results represent new insights 
for the design of modified nucleotides as substrates for KlenTaq DNA polymerase. When designing modified nucleotides based on 7-deaza-dATP, both linkers (alkene and alkyne) should be considered and it might well be that for larger modifications the linkage type makes a difference. If the modification should be attached to dTTP the alkene linkage may be preferred.

\section{Experimental Section}

\section{Chemical synthesis of modified nucleotides}

General experimental details: Succinimidyl 10-hydroxydecanoate, ${ }^{[46]} \quad 2,2,2$-trifluoro- $N$-(pent-4-enyl)acetamide, ${ }^{[47]} \quad 5$-( $N$-(10-hydroxydecanoyl)-aminopentynyl)-2'-deoxyuridine-triphosphate, ${ }^{[28]}$ and 7-(N-(10-hydroxydecanoyl)-aminopentynyl)-7-deaza-2'-deoxyadenosine-triphosphate ${ }^{[28]}$ were prepared according to reported procedures. ${ }^{1} \mathrm{H},{ }^{13} \mathrm{C}$ and ${ }^{31} \mathrm{P} N M R$ spectra were recorded with a Bruker DRX $300 \mathrm{MHz}$ or Avance II $600 \mathrm{MHz}$ instrument. The chemical shifts are referenced to the residual proton signal of the deuterated solvents: $\mathrm{CDCl}_{3}(\delta \quad 7.26 \mathrm{ppm}), \mathrm{MeOD}(\delta \quad 3.31 \mathrm{ppm})$ or

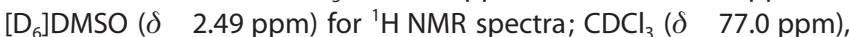
MeOD ( $\delta \quad 49.9 \mathrm{ppm})$ or $\left[\mathrm{D}_{6}\right] \mathrm{DMSO}(\delta \quad 39.5 \mathrm{ppm})$ for ${ }^{13} \mathrm{C} \mathrm{NMR}$ spectra. ${ }^{31} \mathrm{P}$-shifts are relative to external $85 \%$ phosphoric acid. ${ }^{1} \mathrm{H}$ and ${ }^{13} \mathrm{C}$ assignments were based on COSY and HSQC experiments. MS experiments were performed with a Finnigan LCQ Advantage MAX ion trap instrument. Analytical thin-layer chromatography (TLC) was carried out with Macherey Nagel Polygram SIL G/UV254 plates. Flash column chromatography was carried out with silica gel 60 (70 230 mesh). All reactions were carried out under argon atmosphere. Chemical reagents and solvents were purchased from commercial suppliers and used without further purification. Organic solvents for reactions were dried overnight over freshly activated molecular sieves $(4 \AA)$.

\section{Synthesis of 2'-deoxyuridine analogue $\mathrm{dU}^{\text {ene }} \mathrm{TP}$}

5-(Trifluoroacetamidopentenyl)-2'-deoxyuridine 2: To a solution of 5-iodo-2'-deoxyuridine 1 (400 mg, $1.1 \mathrm{mmol})$ in DMF under nitrogen atmosphere, were added 2,2,2-trifluoro- $\mathrm{N}$-(pent-4-enyl)acetamide $\left(1.2 \mathrm{~g}, 6.7 \mathrm{mmol}, 6\right.$ equiv), $\mathrm{Pd}(\mathrm{OAc})_{2}(24 \mathrm{mg}, 0.11 \mathrm{mmol}$, 0.1 equiv), and $\mathrm{PPh}_{3}(58 \mathrm{mg}, 0.22 \mathrm{mmol}, 0.2$ equiv) followed by addition of triethylamine $(308 \mu \mathrm{L}, 2.2 \mathrm{mmol}, 2$ equiv). The reaction mixture was stirred and heated at $100^{\circ} \mathrm{C}$ for $1 \mathrm{~h}$ and then evaporated in vacuo. Complete conversion of the starting material was detected by RP-TLC (MeCN/water, 1:3). The crude mixture was first purified by column chromatography on silica gel $\left(\mathrm{CH}_{2} \mathrm{Cl}_{2} / \mathrm{MeOH}, 0\right.$ to $10 \% \mathrm{MeOH}$ ), and the resulting fractions were further purified by RP-HPLC [Nucleosil 100-5 C18 PPN, 5 100\% acetonitrile/0.05 M aqueous triethylammonium acetate buffer (TEAA buffer, $\mathrm{pH}$ 7.0)] to give modified nucleoside 2 (64 mg, 14\%) as a white solid. RP-TLC (MeCN/water, 1:3): $R_{\mathrm{f}} \quad 0.29 ;{ }^{1} \mathrm{H}$ NMR (400 MHz, $\left.\mathrm{CD}_{3} \mathrm{OD}\right): \delta \quad 8.14(\mathrm{~s}$, $1 \mathrm{H} ; \mathrm{H}-6), 6.46(\mathrm{dt}, J 15.7,7.1 \mathrm{~Hz}, 1 \mathrm{H} ; \mathrm{CH} \mathrm{CH}-\mathrm{CH} 2), 6.33(\mathrm{t}, J$ $\left.6.6 \mathrm{~Hz}, 1 \mathrm{H} ; \mathrm{H}-1^{\prime}\right), 6.20\left(\mathrm{~d}, J 15.7 \mathrm{~Hz}, 1 \mathrm{H} ; \mathrm{CH} \mathrm{CH}-\mathrm{CH}_{2}\right), 4.46(\mathrm{dt}, J$ 7.1, 3.3 Hz, $1 \mathrm{H} ; \mathrm{H}-3^{\prime}$ ), 3.97 (q, J $\left.3.3 \mathrm{~Hz}, 1 \mathrm{H} ; \mathrm{H}-4^{\prime}\right), 3.88$ (dd, J 12.0, $3.3 \mathrm{~Hz}, 1 \mathrm{H}$; Ha-5'), 3.80 (dd, J 12.0, $3.3 \mathrm{~Hz}, 1 \mathrm{H} ; \mathrm{Hb}-5^{\prime}$ ), 3.27 $3.39\left(\mathrm{~m}, 2 \mathrm{H} ; \mathrm{CH}_{2}-\mathrm{NH}\right), 2.242 .43\left(\mathrm{~m}, 2 \mathrm{H} ; \mathrm{H}-2^{\prime}\right), 2.22(\mathrm{q}, J$ 7.4, $\left.7.1 \mathrm{~Hz}, 2 \mathrm{H} ; \mathrm{CH} C \mathrm{CH}-\mathrm{CH}_{2}\right), 1.74 \mathrm{ppm}\left(\mathrm{p}, J 7.4 \mathrm{~Hz}, 2 \mathrm{H} ; \mathrm{CH}_{2}-\mathrm{CH}_{2}-\mathrm{CH}_{2}\right)$; ${ }^{13} \mathrm{C}$ NMR (101 MHz, CD $\left.\mathrm{OD}\right): \delta 164.6(\mathrm{CO}), 151.6(\mathrm{CO}), 137.8$ (C-6), $131.6\left(\mathrm{CH} \mathrm{CH}-\mathrm{CH}_{2}\right), 122.9\left(\mathrm{CH} \mathrm{CH}-\mathrm{CH}_{2}\right), 113.4(\mathrm{C}-5), 80.0\left(\mathrm{C}-4^{\prime}\right), 86.6$ $\left(\mathrm{C}-1^{\prime}\right), 72.0\left(\mathrm{C}-3^{\prime}\right), 62.6\left(\mathrm{C}-5^{\prime}\right), 41.6\left(\mathrm{C}-2^{\prime}\right), 40.3\left(\mathrm{CH}_{2}-\mathrm{NH}\right), 31.6(\mathrm{CH}$ $\left.\mathrm{CH}-\mathrm{CH}_{2}\right), 29.4 \mathrm{ppm}\left(\mathrm{CH}_{2}-\mathrm{CH}_{2}-\mathrm{CH}_{2}\right)$; HRMS (positive mode): $\mathrm{m} / \mathrm{z}$ calcd for $\left[\mathrm{C}_{16} \mathrm{H}_{20} \mathrm{~F}_{3} \mathrm{~N}_{3} \mathrm{O}_{6} \mathrm{Na}\right]^{+}$: 430.1202 ; found: 430.1169 .
5-(Aminopentenyl)-2'-deoxyuridinetriphosphate 3: Nucleoside 2 (40 $\mathrm{mg}, 100 \mu \mathrm{mol})$ and proton sponge (1,8-bis(dimethylaminonaphthalene)) ( $32 \mathrm{mg}, 149 \mu \mathrm{mol})$ were dried overnight in vacuo and dissolved in trimethyl phosphate $(1 \mathrm{~mL})$ and cooled to $0^{\circ} \mathrm{C}$. $\mathrm{POCl}_{3}$ ( $20 \mu \mathrm{L}, 218 \mu \mathrm{mol})$ was added and the mixture was stirred for $1 \mathrm{~h}$ at RT. A $0.5 \mathrm{M}$ solution of $\left(\mathrm{Bu}_{3} \mathrm{NH}\right)_{2} \mathrm{H}_{2} \mathrm{P}_{2} \mathrm{O}_{7}$ in anhydrous DMF $(1.2 \mathrm{~mL}$, $493 \mu \mathrm{mol})$ and $n \mathrm{Bu}_{3} \mathrm{~N}(261 \mu \mathrm{L}, 987 \mu \mathrm{mol})$ were added simultaneously to the mixture. After $30 \mathrm{~min}, 0.1 \mathrm{M}$ aqueous triethylammonium bicarbonate (TEAB buffer, $1 \mathrm{~m}$ triethylamine, saturated with $\mathrm{CO}_{2}, \mathrm{pH} 7.5,3 \mathrm{~mL}$ ) was added and the aqueous layer was washed with EtOAc $(3 \times 4 \mathrm{~mL})$. The aqueous layer was evaporated under vacuum. The residue was dissolved in $40 \mathrm{~mL}$ of a solution of ammonium hydroxide $(25 \%)$ and the mixture was stirred slowly at RT for $4 \mathrm{~h}$. The mixture was concentrated in vacuo and the resulting residue was purified by ion-exchange chromatography (DEAE-Sephadex A-25, flow $2 \mathrm{~mL}$ min ${ }^{~}$, linear gradient of $0.1 \mathrm{M}$ to $1 \mathrm{M} \mathrm{TEAB}$ buffer) and further purified by RP-HPLC (VP 250/16 NUCLEODUR C18 HTec column, linear gradient from 5 to $100 \% \mathrm{MeCN}$ in $0.05 \mathrm{M}$ TEAA buffer $(0.05 \mathrm{~m}$ acetic acid, $0.05 \mathrm{M}$ triethylamine, $\mathrm{pH} 7.0))$ to give triphosphate $3(5,5 \mathrm{mg}, 10 \mu \mathrm{mol}, 10 \%)$. ${ }^{1} \mathrm{H} \mathrm{NMR}(400 \mathrm{MHz}$, $\left.\mathrm{D}_{2} \mathrm{O}\right): \delta \quad 7.95(\mathrm{~s}, 1 \mathrm{H} ; \mathrm{H}-6), 6.43(\mathrm{dt}, J \quad 16.1,6.5 \mathrm{~Hz}, 1 \mathrm{H}$; $\mathrm{CH} \mathrm{CH}-$ $\left.\mathrm{CH}_{2}\right), 6.36\left(\mathrm{t}, J 6.3 \mathrm{~Hz}, 1 \mathrm{H} ; \mathrm{H}^{\prime} \mathbf{1}^{\prime}\right), 6.27(\mathrm{~d}, J 16.1 \mathrm{~Hz}, 1 \mathrm{H} ; \mathrm{CH} \mathrm{CH}-$ $\left.\mathrm{CH}_{2}\right), 4.70\left(\mathrm{q}, J 4.8 \mathrm{~Hz}, 1 \mathrm{H} ; \mathrm{H}-3^{\prime}\right), 4.334 .24\left(\mathrm{~m}, 1 \mathrm{H} ; \mathrm{H}-4^{\prime}\right), 4.26$ $4.16\left(\mathrm{~m}, 2 \mathrm{H} ; \mathrm{H}-5^{\prime}\right), 3.04\left(\mathrm{t}, J 6.5 \mathrm{~Hz}, 1 \mathrm{H} ; \mathrm{CH}_{2}-\mathrm{NH}_{2}\right), 2.41(\mathrm{t}, J$ $\left.6.3 \mathrm{~Hz}, 2 \mathrm{H} ; \mathrm{H}-2^{\prime}\right), 2.31$ (q, J $6.5 \mathrm{~Hz}, 2 \mathrm{H} ; \mathrm{CH} \mathrm{CH}_{-} \mathrm{CH}_{2}$ ), $1.88 \mathrm{ppm}(\mathrm{p}$, J $\left.6.5 \mathrm{~Hz}, 2 \mathrm{H} ; \mathrm{CH}_{2}-\mathrm{CH}_{2}-\mathrm{CH}_{2}-\mathrm{NH}_{2}\right) ;{ }^{13} \mathrm{C}$ NMR $\left(101 \mathrm{MHz}, \mathrm{D}_{2} \mathrm{O}\right): \delta$ 164.6, 151.0, 136.8, 131.4, 121.2, 113.0, 85.7, 85.2, 70.5, 65.2, 39.1, 38.6, 28.9, 25.7 ppm; ${ }^{31} \mathrm{P} N M R\left(162 \mathrm{~Hz}, \mathrm{D}_{2} \mathrm{O}\right): \delta \quad 7.11$ (d, J $20.2 \mathrm{~Hz}, 1 \mathrm{P} ; \mathrm{P} \gamma), 11.24$ (d, J $19.1 \mathrm{~Hz}, 1 \mathrm{P} ; \mathrm{P \alpha}), 21.91 \mathrm{ppm}(\mathrm{t}, J$ $20.2 \mathrm{~Hz}, 1 \mathrm{P}$; $\mathrm{P} \beta$ ); HRMS (negative mode): $\mathrm{m} / \mathrm{z}$ calcd for $\left[\mathrm{C}_{14} \mathrm{H}_{23} \mathrm{~N}_{3} \mathrm{O}_{14} \mathrm{P}_{3}\right]: 550.0415$; found: 550.0403 .

5-(N-(10-Hydroxydecanoyl)aminopentenyl)-2'-deoxyuridinetriphosphate dU ${ }^{\text {ene }}$ TP: To a solution of 5-(aminopentenyl)-2'-deoxyuridinetriphosphate $3(10 \mu \mathrm{mol})$ in $400 \mu \mathrm{L}$ of sodium carbonate buffer $(0.1 \mathrm{M}, \mathrm{pH} 8.7)$ was added a solution of succinimidyl 10-hydroxydecanoate ( $20 \mathrm{mg}, 70 \mu \mathrm{mol}, 7$ equiv) in DMF $(400 \mu \mathrm{L})$. The reaction was stirred slowly at RT for $2 \mathrm{~h}$. The solution was filtered before purification by RP-HPLC [VP 250/8 NUCLEODUR C18 HTec column, $5100 \%$ acetonitrile/0.1 M TEAA buffer $(\mathrm{pH} 7.0)]$ to give triphosphate dU ${ }^{\text {ene }}$ TP in quantitative yield. ${ }^{1} \mathrm{H}$ NMR $\left(400 \mathrm{MHz}, \mathrm{D}_{2} \mathrm{O}\right)$ : $\delta 7.90(\mathrm{~s}, 1 \mathrm{H} ; \mathrm{H}-6), 6.49\left(\mathrm{dt}, J \quad 16.0,6.9 \mathrm{~Hz}, 1 \mathrm{H} ; \mathrm{CH} \mathrm{CH}-\mathrm{CH}_{2}\right)$, $6.38\left(\mathrm{t}, J 7.0 \mathrm{~Hz}, 1 \mathrm{H} ; \mathrm{H}^{\prime} 1^{\prime}\right), 6.23\left(\mathrm{~d}, J 16.0 \mathrm{~Hz}, 1 \mathrm{H} ; \mathrm{CH} \mathrm{CH}_{-} \mathrm{CH}_{2}\right)$, $4.744 .66\left(\mathrm{~m}, 1 \mathrm{H} ; \mathrm{H}-3^{\prime}\right), 4.364 .12\left(\mathrm{~m}, 3 \mathrm{H} ; \mathrm{H}-4^{\prime}\right.$ and $\left.\mathrm{H}-5^{\prime}\right), 3.60(\mathrm{t}$, J $\left.6.7 \mathrm{~Hz}, 2 \mathrm{H} ; \mathrm{CH}_{2}-\mathrm{OH}\right), 3.323 .18\left(\mathrm{~m}, 19 \mathrm{H} ; \mathrm{CH}_{2}-\mathrm{NH}-\right.$, superimposed by TEA), $2.512 .37\left(\mathrm{~m}, 2 \mathrm{H} ; \mathrm{H}-2^{\prime}\right), 2.332 .24\left(\mathrm{~m}, 2 \mathrm{H} ; \mathrm{CH} \mathrm{CH}-\mathrm{CH}_{2}\right)$, $2.23\left(\mathrm{t}, J \quad 7.4 \mathrm{~Hz}, 2 \mathrm{H} ; \mathrm{NH}-\mathrm{CO}-\mathrm{CH}_{2}\right), 1.72\left(\mathrm{p}, J 6.9 \mathrm{~Hz}, 2 \mathrm{H} ; \mathrm{CH}_{2}-\mathrm{CH}_{2}-\right.$ $\left.\mathrm{CH}_{2}-\mathrm{NH}\right), 1.611 .48\left(\mathrm{~m}, 4 \mathrm{H} ; 2 \times \mathrm{CH}_{2}\right), 1.381 .18 \mathrm{ppm}(\mathrm{m}, 36 \mathrm{H} ; 5 \times$ $\mathrm{CH}_{2}$, superimposed by TEA); ${ }^{31} \mathrm{P}$ NMR $\left(162 \mathrm{MHz}, \mathrm{D}_{2} \mathrm{O}\right): \delta \quad 10.75$ (d, J $14.2 \mathrm{~Hz}, 1 \mathrm{P} ; \mathrm{P} \gamma$ ), 11.59 (d, J $19.6 \mathrm{~Hz}, 1 \mathrm{P} ; \mathrm{P \alpha}$ ), 22.62 $23.74(\mathrm{~m}, 1 \mathrm{P} ; \mathrm{P} \beta)$; HRMS (negative mode): $\mathrm{m} / \mathrm{z}$ calcd for $\left[\mathrm{C}_{24} \mathrm{H}_{41} \mathrm{~N}_{3} \mathrm{O}_{16} \mathrm{P}_{3}\right]: 720.1722$; found: 720.1736 .

\section{Synthesis of 2'-deoxyadenosine analogue $d A^{\text {ene }}$ TP}

7-Deaza-2'-deoxy-7-vinyladenosine 5: To 7-deaza-2'-deoxy-7-iodoadenosine $4(500 \mathrm{mg}, 1.329 \mathrm{mmol})$ in DMF $(10 \mathrm{~mL})$ were added subsequently tetrakis(triphenylphosphine)palladium (150 mg, $0.133 \mathrm{mmol}, 0.1$ equiv) and tributyl(vinyl)tin $(1.555 \mathrm{~mL}, 5.317 \mathrm{mmol}$, 4 equiv). The mixture was stirred and heated at $100^{\circ} \mathrm{C}$ for $2 \mathrm{~h}$. After cooling, the solvent was removed under vacuum. The crude mixture was purified by silica gel column chromatography $\left(\mathrm{CH}_{2} \mathrm{Cl}_{2} /\right.$ $\mathrm{MeOH}, 9: 1)$ to give 5 (314 mg, 86\%) as a yellow solid. ${ }^{1} \mathrm{H}$ NMR (400 MHz, CD $\mathrm{OD}$ ): $\delta \quad 8.07$ (s, 1 H; H-2), $7.51(\mathrm{~s}, 1 \mathrm{H} ; \mathrm{H}-8), 7.00$ (dd, J $\left.17.3,11.0 \mathrm{~Hz}, 1 \mathrm{H} ;-\mathrm{CH} \mathrm{CH}_{2}\right), 6.51\left(\mathrm{dd}, J 8.3,6.0 \mathrm{~Hz}, 1 \mathrm{H} ; \mathrm{H}^{\prime} \mathbf{1}^{\prime}\right)$, 
$5.59\left(\mathrm{dd}, J 17.3,1.6 \mathrm{~Hz}, 1 \mathrm{H}\right.$; $\left.-\mathrm{CH} \mathrm{CH} \mathrm{CH}_{2}\right), 5.26(\mathrm{dd}, J 11.0,1.6 \mathrm{~Hz}$, $\left.1 \mathrm{H} ;-\mathrm{CH} \mathrm{CH})_{2}\right), 4.53\left(\mathrm{dt}, J 6.0,2.6 \mathrm{~Hz}, 1 \mathrm{H} ; \mathrm{H}-3^{\prime}\right), 4.01(\mathrm{q}, J 3.3 \mathrm{~Hz}$, $\left.1 \mathrm{H} ; \mathrm{H}-4^{\prime}\right), 3.863 .69\left(\mathrm{~m}, 2 \mathrm{H} ; \mathrm{H}-5^{\prime}\right), 2.67$ (ddd, J 13.7, 8.3, $6.0 \mathrm{~Hz}$ $\left.1 \mathrm{H} ; \mathrm{H}-2^{\prime}\right), 2.31 \mathrm{ppm}\left(\mathrm{ddd}, J \quad 13.7,6.0,2.6 \mathrm{~Hz}, 1 \mathrm{H} ; \mathrm{H}-2^{\prime}\right) ;{ }^{13} \mathrm{C} \mathrm{NMR}$ $\left(101 \mathrm{MHz}, \mathrm{CD}_{3} \mathrm{OD}\right): \delta 159.3(\mathrm{Cq}), 152.1$ (C2), 151.1 (Cq), 129.6 $\left.(-\mathrm{CH} \mathrm{CH})_{2}\right), 121.3(\mathrm{C} 8), 116.6,115.5\left(-\mathrm{CH} \mathrm{CH}_{2}\right), 103.0(\mathrm{Cq}), 100.2$ $(\mathrm{Cq}), 89.0\left(\mathrm{C}^{\prime}\right), 86.5\left(\mathrm{C1}^{\prime}\right), 73.0\left(\mathrm{C} 3^{\prime}\right), 63.7\left(\mathrm{C}^{\prime}\right), 41.4 \mathrm{ppm}\left(\mathrm{C} 2^{\prime}\right)$; HRMS (positive mode): $\mathrm{m} / \mathrm{z}$ calcd for $\left[\mathrm{C}_{13} \mathrm{H}_{17} \mathrm{~N}_{4} \mathrm{O}_{3}\right]^{+}:$277.1301; found: 277.1303 .

7-Deaza-2'-deoxy-3',5'-dibenzoate-6N,6N-dibenzoyl-7-vinyladenosine (6): To 7-deaza-2'-deoxy-7-vinyladenosine 5 (600 mg, $2.173 \mathrm{mmol})$ in anhydrous pyridine $(10 \mathrm{~mL})$ at $0{ }^{\circ} \mathrm{C}$ was added benzoylchloride $(1.514 \mathrm{~mL}, 13.038 \mathrm{mmol})$ over $30 \mathrm{~min}$. The mixture was then stirred at RT for $2 \mathrm{~h}$. Water was slowly added and the solution was extracted with dichloromethane. The combined organic layers were dried $\left(\mathrm{MgSO}_{4}\right)$, filtered, evaporated, and the residue was purified by silica gel column chromatography (petroleum ether/EtOAc, $8: 2$ to $4: 6)$ to give protected adenosine $6(1.253 \mathrm{~g}, 83 \%)$ as a yellow solid. M.p. $62^{\circ} \mathrm{C} ;{ }^{1} \mathrm{H}$ NMR $\left(400 \mathrm{MHz}, \mathrm{CDCl}_{3}\right): \delta \quad 8.59(\mathrm{~s}$, $1 \mathrm{H} ; \mathrm{H}-2), 8.188 .04(\mathrm{~m}, 4 \mathrm{H} ; \mathrm{Bz}), 7.907 .81(\mathrm{~m}, 4 \mathrm{H} ; \mathrm{Bz}), 7.747 .29$ $(\mathrm{m}, 13 \mathrm{H} ; \mathrm{Bz}$ and $\mathrm{H}-8), 6.93\left(\mathrm{dd}, J 8.7,6.0 \mathrm{~Hz}, 1 \mathrm{H} ; \mathrm{H}-1^{\prime}\right), 6.70(\mathrm{dd}$, J $\left.17.4,10.8 \mathrm{~Hz}, 1 \mathrm{H} ;-\mathrm{CH} \mathrm{CH}_{2}\right), 5.83\left(\mathrm{dt}, J 6.0,2.2 \mathrm{~Hz}, 1 \mathrm{H} ; \mathrm{H}-3^{\prime}\right)$, 5.29 (dd, J 17.4, $1.3 \mathrm{~Hz}, 1 \mathrm{H}$; $-\mathrm{CH} \mathrm{CH}$ ), 5.00 (dd, J 10.8, $1.3 \mathrm{~Hz}$, $\left.1 \mathrm{H} ;-\mathrm{CH} \mathrm{CH} \mathrm{CH}_{2}\right), 4.84\left(\mathrm{dd}, J\right.$ 12.0, $\left.3.6 \mathrm{~Hz}, 1 \mathrm{H} ; \mathrm{H}-5^{\prime}\right), 4.73$ (dd, J 12.0, $\left.3.6 \mathrm{~Hz}, 1 \mathrm{H} ; \mathrm{H}-5^{\prime}\right), 4.674 .62\left(\mathrm{~m}, 1 \mathrm{H} ; \mathrm{H}-4^{\prime}\right), 2.982 .67$ ppm (m, $\left.2 \mathrm{H} ; \mathrm{H}-2^{\prime}\right) ;{ }^{13} \mathrm{C}$ NMR $\left(101 \mathrm{MHz}, \mathrm{CDCl}_{3}\right): \delta 172.8,166.3,166.2(3 \times$ CO), 153.3, 153.2 (C4 and C6), 151.4 (C2), 133.8, 133.65, 133.61, 133.0, 130.2, 130.0, 129.8, 129.6, 129.4, 129.4, 129.3, 129.0, 128.9, 128.7, 128.6, $126.9\left(-\mathrm{CH} \mathrm{CH}_{2}\right), 122.4(\mathrm{C} 8), 116.4\left(-\mathrm{CH} \mathrm{CH}_{2}\right), 115.4$ (C7), 113.1 (C5), $84.0\left(\mathrm{C}^{\prime}{ }^{\prime}\right), 82.6\left(\mathrm{C}^{\prime}\right), 75.5\left(\mathrm{C}^{\prime}\right), 64.5\left(\mathrm{C}^{\prime}\right), 38.5 \mathrm{ppm}$ (C2').

7-Deaza-2'-deoxy-3',5'-dibenzoate-6N,6N-dibenzoyl-7-(trifluoroacetamidopentenyl)adenosine (7E/Z): A solution of adenosine 6 $(200 \mathrm{mg}, 0.289 \mathrm{mmol})$ in anhydrous toluene $(5 \mathrm{~mL})$ was degassed $5 \mathrm{~min}$. The pentenyltrifluoroacetamide $(520 \mu \mathrm{L}, 2.89 \mathrm{mmol}$, 10 equiv) was added and the solution was degassed for $5 \mathrm{~min}$. The solution was heated to $100^{\circ} \mathrm{C}$ and Grubbs II catalyst ( $48 \mathrm{mg}, 20 \%$ ) was added by portions ( $16 \mathrm{mg}$, every $30 \mathrm{~min}$ ). After $2 \mathrm{~h}$, the solution was cool and the solvent was evaporated. The residue was purified by silica gel chromatography (petroleum ether/EtOAc, 7:3) to afford $7 E / Z(108 \mathrm{mg}, 45 \%)$ as a mixture of diastereoisomers $(E / Z$, $3: 1)$.

7-Deaza-2'-deoxy-7-(trifluoroacetamidopentenyl)adenosine (8E): The mixture of diastereoisomers $7 E / Z(217 \mathrm{mg}, 0.257 \mathrm{mmol})$ in a 7 $\mathrm{N}$ ammonia solution in methanol $(5 \mathrm{~mL})$ was stirred in a closed vial at $50^{\circ} \mathrm{C}$ overnight. The mixture was concentrated in vacuo and the resulting residue was first purified by column chromatography on silica gel $\left(\mathrm{CH}_{2} \mathrm{Cl}_{2} / \mathrm{MeOH}, 9: 1\right)$ giving compound $8 \mathrm{E} / \mathrm{Z}$ (80 mg, $\left.72 \%\right)$ as an $E / Z$ mixture and complete deprotected compound $9 E / Z$ (20 $\mathrm{mg}, 23 \%$ ) as an $E / Z$ mixture.

To compound $9 E / Z$ (20 mg, $0.060 \mathrm{mmol}$ ) in THF $(0.5 \mathrm{~mL})$ was added ethyl trifluoroacetate ( $8 \mu \mathrm{L}, 0.066 \mathrm{mmol}, 1.1$ equiv) and DMAP $(0.7 \mathrm{mg}, 0.006 \mathrm{mmol}, 0.1$ equiv). The solution was stirred at $90^{\circ} \mathrm{C}$ for $4 \mathrm{~h}$ and the resulting residue was first purified by column chromatography on silica gel $\left(\mathrm{CH}_{2} \mathrm{Cl}_{2} / \mathrm{MeOH}, 9: 1\right)$ affording $8 E / Z$ $(12 \mathrm{mg}, 47 \%)$ as a mixture of diastereoisomers $(E / Z, 3: 1)$.

The combined fractions of $8 E / Z$ ( $92 \mathrm{mg}$ ) were purified by RP-HPLC (VP 250/16 NUCLEODUR C18 HTec column, 5 100\% acetonitrile/ water) to give pure trans-alkene nucleoside $8 E(28 \mathrm{mg}, 27 \%)$ as a white solid. ${ }^{1} \mathrm{H}$ NMR $\left(400 \mathrm{MHz}, \mathrm{CD}_{3} \mathrm{OD}\right): \delta \quad 8.08(\mathrm{~s}, 1 \mathrm{H} ; \mathrm{H}-2), 7.42$ (s, $1 \mathrm{H} ; \mathrm{H}-8), 6.69$ (dd, J 15.5, 1.1 Hz, 1 H; CH CH-CH $), 6.53(\mathrm{dd}$, J $\left.8.3,5.9 \mathrm{~Hz}, 1 \mathrm{H} ; \mathrm{H}^{\prime} 1^{\prime}\right), 6.06(\mathrm{dt}$, J $15.6,7.0 \mathrm{~Hz}, 1 \mathrm{H} ;-\mathrm{CH} \mathrm{CH}-$ $\left.\mathrm{CH}_{2}\right), 4.55\left(\mathrm{dt}, J \quad 5.6,2.6 \mathrm{~Hz}, 1 \mathrm{H} ; \mathrm{H}-3^{\prime}\right), 4.03\left(\mathrm{q}, J \quad 3.3 \mathrm{~Hz}, 1 \mathrm{H} ; \mathrm{H}-4^{\prime}\right)$,
$3.883 .66\left(\mathrm{~m}, 2 \mathrm{H} ; \mathrm{H}-5^{\prime}\right), 3.40\left(\mathrm{t}, J \quad 7.0 \mathrm{~Hz}, 2 \mathrm{H} ;-\mathrm{CH}_{2}-\mathrm{NH}\right), 2.69$ (ddd, J $\left.13.4,8.3,6.0 \mathrm{~Hz}, 1 \mathrm{H} ; \mathrm{H}-2^{\prime}\right), 2.422 .21\left(\mathrm{~m}, 3 \mathrm{H} ; \mathrm{H}-2^{\prime}\right.$ and $-\mathrm{CH} \mathrm{CH}-$ $\left.\mathrm{CH}_{2}-\right), \quad 1.79 \mathrm{ppm} \quad\left(\mathrm{p}, \quad J \quad 7.1 \mathrm{~Hz}, \quad 2 \mathrm{H} ; \quad-\mathrm{CH}_{2}-\mathrm{CH}_{2}-\mathrm{CH}_{2}-\right) ;{ }^{13} \mathrm{C} \mathrm{NMR}$ $\left(101 \mathrm{MHz}, \mathrm{CD}_{3} \mathrm{OD}\right): \delta 159.2(\mathrm{Cq}), 151.9$ (C2), 150.8 (Cq), 132.2 $\left(-\mathrm{CH} \mathrm{CH}-\mathrm{CH}_{2}\right), 123.2\left(-\mathrm{CH} \mathrm{CH}-\mathrm{CH}_{2}\right), 120.6(\mathrm{C} 8), 116.2(\mathrm{Cq}), 103.1$ $(\mathrm{Cq}), 89.0\left(\mathrm{C}-4^{\prime}\right), 86.4\left(\mathrm{C}-1^{\prime}\right), 73.0\left(\mathrm{C}-3^{\prime}\right), 63.7\left(\mathrm{C}-5^{\prime}\right), 41.3\left(\mathrm{C} 2^{\prime}\right), 39.9$ $\left(-\mathrm{CH}_{2}-\mathrm{NH}\right), 30.9\left(-\mathrm{CH} \quad \mathrm{CH}-\mathrm{CH}_{2}-\right), 29.5 \mathrm{ppm}\left(-\mathrm{CH}_{2}-\mathrm{CH}_{2}-\mathrm{CH}_{2}-\right)$; HRMS (positive mode): $\mathrm{m} / \mathrm{z}$ calcd for $\left[\mathrm{C}_{18} \mathrm{H}_{23} \mathrm{~F}_{3} \mathrm{~N}_{5} \mathrm{O}_{4}\right]^{+}: 230.1702$; found: 230.1693.

7-(Aminopentenyl)-7-deaza-2'-deoxyadenosinetriphosphate 10: Nucleoside $8 E(65 \mathrm{mg}, 152 \mu \mathrm{mol})$ and proton sponge (1,8-bis(dimethylaminonaphthalene)) $(49 \mathrm{mg}, 229 \mu \mathrm{mol})$ were dried overnight in vacuum, dissolved in trimethyl phosphate $(3.25 \mathrm{~mL})$, and cooled to $0{ }^{\circ} \mathrm{C}$. $\mathrm{POCl}_{3}(28 \mu \mathrm{L}, 218 \mu \mathrm{mol})$ was added and the mixture was stirred for $1 \mathrm{~h}$ at RT. A $0.5 \mathrm{M}$ solution of $\left(\mathrm{Bu}_{3} \mathrm{NH}\right)_{2} \mathrm{H}_{2} \mathrm{P}_{2} \mathrm{O}_{7}$ in anhydrous DMF $(1.5 \mathrm{~mL}, 760 \mu \mathrm{mol})$ and $n \mathrm{Bu}_{3} \mathrm{~N}(361 \mu \mathrm{L}, 1.52 \mathrm{mmol})$ were added simultaneously to the mixture. After $30 \mathrm{~min}, 0.1 \mathrm{M}$ aqueous triethylammonium bicarbonate (TEAB buffer, pH 7.5, $6 \mathrm{~mL}$ ) was added and the aqueous layer was washed with EtOAc $(3 \times 6 \mathrm{~mL})$. The aqueous layer was evaporated under vacuum. The residue was dissolved in $45 \mathrm{~mL}$ of a solution of ammonium hydroxide (25\%) and the reaction was stirred slowly at RT for $4 \mathrm{~h}$. The mixture was concentrated in vacuo and the resulting residue was purified by ion-exchange chromatography (DEAE-Sephadex A-25, linear gradient of TEAB buffer $(0.1 \mathrm{M}$ to $1 \mathrm{M}, 1000 \mathrm{~mL})$, flow $\left.2 \mathrm{~mL} \min { }^{1}\right)$ and further purified by RP-HPLC (VP 250/16 NUCLEODUR C18 HTec column, linear gradient from 5 to $100 \% \mathrm{MeCN}$ in $0.05 \mathrm{M}$ TEAA buffer $(\mathrm{pH} 7.0))$ to give the triphosphate $10(19.8 \mu \mathrm{mol}, 14 \%)$. ${ }^{1} \mathrm{H}$ NMR (400 MHz, CD $\left.\mathrm{OD}\right): \delta \quad 8.05(\mathrm{~s}, 1 \mathrm{H} ; \mathrm{H}-6), 7.85(\mathrm{~s}, 1 \mathrm{H} ; \mathrm{H}-2)$, $6.716 .59\left(\mathrm{~m}, 2 \mathrm{H} ; \mathrm{H}-1^{\prime}\right.$ and $\left.\mathrm{CH} C H-\mathrm{CH}_{2}\right), 6.28(\mathrm{dt}, J 14.7,6.9 \mathrm{~Hz}$, $\left.1 \mathrm{H} ; \mathrm{CH} \quad \mathrm{CH}-\mathrm{CH}_{2}\right), 4.784 .70\left(\mathrm{~m}, 1 \mathrm{H} ; \mathrm{H}-3^{\prime}\right), 4.314 .22\left(\mathrm{~m}, 2 \mathrm{H} ; \mathrm{H}-5^{\prime}\right)$, $4.074 .01\left(\mathrm{~m}, 1 \mathrm{H} ; \mathrm{H}-4^{\prime}\right), 3.263 .01\left(\mathrm{~m}, 15 \mathrm{H} ; \mathrm{CH}_{2}-\mathrm{NH}_{2}\right.$ superimposed by TEA), $2.582 .48\left(\mathrm{~m}, 1 \mathrm{H} ; \mathrm{H}-2^{\prime}\right), 2.442 .24\left(\mathrm{~m}, 3 \mathrm{H} ; \mathrm{H}-2^{\prime}\right.$ and $\mathrm{CH}$ $\left.\mathrm{CH}-\mathrm{CH}_{2}\right), \quad 1.931 .83 \mathrm{ppm} \quad\left(\mathrm{m}, 2 \mathrm{H} ; \quad \mathrm{CH}_{2}-\mathrm{CH}_{2}-\mathrm{CH}_{2}-\mathrm{NH}_{2}\right)$; ${ }^{31} \mathrm{P} \mathrm{NMR}$ (162 MHz, CD $\left.{ }_{3} \mathrm{OD}\right): \delta \quad 10.97(\mathrm{~d}, J 20.5 \mathrm{~Hz} ; \mathrm{P} \gamma), 11.93$ (d, J $19.9 \mathrm{~Hz} ; \mathrm{P} \alpha), \quad 23.72 \mathrm{ppm}(\mathrm{t}, J 19.9 \mathrm{~Hz} ; \mathrm{P} \beta$ ); HRMS (negative mode): $\mathrm{m} / z$ calcd for $\left[\mathrm{C}_{16} \mathrm{H}_{25} \mathrm{~N}_{5} \mathrm{O}_{12} \mathrm{P}_{3}\right]: 572.0735$; found: 572.0759 .

7-(N-(10-Hydroxydecanoyl)-aminopentenyl)-7-deaza-2 '-deoxyadenosinetriphosphate $\mathrm{dA}{ }^{\text {ene }} \mathrm{TP}$ : To a solution of 7-(aminopentenyl)-7-deaza-2'-deoxyadenosinetriphosphate $10(6.6 \mu \mathrm{mol})$ in $300 \mu \mathrm{L}$ of sodium carbonate buffer $(0.1 \mathrm{M}, \mathrm{pH} 8.7)$ was added a solution of succinimidyl 10-hydroxydecanoate $(9.4 \mathrm{mg}, 33 \mu \mathrm{mol}, 5$ equiv) in DMF $(300 \mu \mathrm{L})$. The reaction was stirred slowly at RT for $2 \mathrm{~h}$. The solution was filtered before purification by RP-HPLC (VP 250/8 NUCLEODUR C18 HTec column, $5100 \%$ acetonitrile/0.05 M TEAA buffer $(\mathrm{pH} 7.0))$ to give triphosphate $d A^{\text {ene }} T P$ in quantitative yield. ${ }^{1} \mathrm{H}$ NMR $\left(400 \mathrm{MHz}, \mathrm{CD}_{3} \mathrm{OD}\right): \delta 8.23(\mathrm{~s}, 1 \mathrm{H} ; \mathrm{H}-2), 7.68(\mathrm{~s}, 1 \mathrm{H} ; \mathrm{H}-8)$, $6.63\left(\mathrm{t}, J 6.7 \mathrm{~Hz}, 1 \mathrm{H} ; \mathrm{H}-1^{\prime}\right), 6.27\left(\mathrm{~d}, J 15.5 \mathrm{~Hz}, 1 \mathrm{H} ; \mathrm{CH} \mathrm{CH}-\mathrm{CH}_{2}\right)$, $6.16\left(\mathrm{dt}, J \quad 15.5,6.6 \mathrm{~Hz}, 1 \mathrm{H} ; \mathrm{CH} \mathrm{CH}-\mathrm{CH}_{2}\right), 4.754 .62\left(\mathrm{~m}, 1 \mathrm{H} ; \mathrm{H}-3^{\prime}\right)$, $4.364 .26\left(\mathrm{~m}, 2 \mathrm{H} ; \mathrm{H}-5^{\prime}\right), 4.16-4-13\left(\mathrm{~m}, 1 \mathrm{H} ; \mathrm{H}^{\prime} 4^{\prime}\right), 3.55(\mathrm{t}$, J $6.7 \mathrm{~Hz}$; $\left.\mathrm{CH}_{2}-\mathrm{OH}\right), 3.573 .08\left(\mathrm{~m}, 14 \mathrm{H} ; \mathrm{CH}_{2}-\mathrm{NH}\right.$ - superimposed by TEA), 2.56 $2.46\left(\mathrm{~m}, 1 \mathrm{H} ; \mathrm{H}-2^{\prime}\right), 2.392 .28\left(\mathrm{~m}, 1 \mathrm{H} ; \mathrm{H}-2^{\prime}\right), 2.272 .19(\mathrm{~m}, 2 \mathrm{H} ; \mathrm{CH}$ $\left.\mathrm{CH}-\mathrm{CH}_{2}\right), 1.801 .67\left(\mathrm{~m}, 4 \mathrm{H} ; \mathrm{CH}_{2}-\mathrm{CH}_{2}-\mathrm{CH}_{2}-\mathrm{NH}-\right.$ and $\left.\mathrm{CO}^{-} \mathrm{CH}_{2}\right), 1.67$ $1.58\left(\mathrm{~m}, 2 \mathrm{H} ;-\mathrm{CO}^{-} \mathrm{CH}_{2}-\mathrm{CH}_{2}-\right), 1.581 .48\left(\mathrm{~m}, 2 \mathrm{H} ;-\mathrm{CH}_{2}-\mathrm{CH}_{2}-\mathrm{OH}\right), 1.41$ $1.21 \mathrm{ppm}\left(\mathrm{m}, 28 \mathrm{H} ; 5 \times \mathrm{CH}_{2}\right.$ superimposed by TEA); ${ }^{31} \mathrm{P}$ NMR (162 MHz, CD $\left.{ }_{3} \mathrm{OD}\right): \delta \quad 9.95$ (d, J $\left.19.6 \mathrm{~Hz} ; \mathrm{P} \gamma\right), 10.75$ (d, J $20.8 \mathrm{~Hz} ; \mathrm{P \alpha}$ ), 22.95 to $23.69 \mathrm{ppm}(\mathrm{m}$; $\mathrm{P} \beta$ ); HRMS (negative mode): $\mathrm{m} / \mathrm{z}$ calcd for $\left[\mathrm{C}_{26} \mathrm{H}_{43} \mathrm{~N}_{5} \mathrm{O}_{14} \mathrm{P}_{3}\right]: 742.2019$; found: 742.2010 .

\section{Primer extension reactions}

KlenTaq DNA polymerase was expressed and purified as described before. ${ }^{[48]}$ T4 polynucleotide kinase PNK was purchased from New 
England Biolabs. Primer and template were purchased from Biomers. $\left[\gamma^{32}\right.$ P]ATP was purchased from Hartmann Analytics and natural dNTPs from ThermoFisher. Sequences of oligonucleotides are given in the Supporting Information.

\section{5'-Radioactive labelling of ODNs}

DNA oligonucleotide primers were radioactively labelled at the $5^{\prime}$ terminus using T4 PNK and $\left[\gamma^{-32} \mathrm{P}\right]$ ATP. The reaction mixture contained primer $(0.4 \mu \mathrm{M})$, PNK reaction buffer $(1 \times), \quad\left[\gamma^{-32}\right.$ P]ATP $\left(0.4 \mu \mathrm{Ci} \mu \mathrm{L}^{1}\right)$ and T4 PNK $\left(0.4 \mathrm{U}_{\mu \mathrm{L}}{ }^{1}\right)$ in a total volume of $50 \mu \mathrm{L}$ and were incubated for $1 \mathrm{~h}$ at $37^{\circ} \mathrm{C}$. The reaction was stopped by incubation for $2 \mathrm{~min}$ at $95^{\circ} \mathrm{C}$ and purified by gel filtration (MicroSpin Sephadex G-25).

\section{Full-length incorporation}

Primer extension reaction (10 $\mu \mathrm{L})$ employing KlenTaq DNA polymerase contained $1 \times$ KlenTaq reaction buffer $(50 \mathrm{~mm}$ Tris $\mathrm{HCl}$ (pH 9.2), $16 \mathrm{~mm}\left(\mathrm{NH}_{4}\right)_{2} \mathrm{SO}_{4}, 2.5 \mathrm{~mm} \mathrm{MgCl} 2,0.1 \%$ Tween 20), $150 \mathrm{~nm}$ ${ }^{32} \mathrm{P}$-labeled primer, $200 \mathrm{nM}$ template, $50 \mu \mathrm{M}$ of modified $\mathrm{dN}^{\mathrm{R} T P}$ and $50 \mu \mathrm{M}$ each of dATP/dTTP, dCTP, dGTP, and 8 nм KlenTaq DNA polymerase. First primer and template were annealed. Afterwards the primer template complex, nucleotides and KlenTaq DNA polymerase were incubated $\left(55^{\circ} \mathrm{C} ; 30 \mathrm{~min}\right)$. The reactions were quenched by addition of $50 \mu \mathrm{L}$ PAGE gel loading buffer/stop solution ( $80 \%$ formamide, $20 \mathrm{~mm}$ EDTA, $0.1 \%$ bromophenol blue, $0.1 \%$ xylene cyanole FF) and the product mixtures were analysed by $12 \%$ denaturing polyacrylamide gel and subjected to autoradiography.

\section{Competition experiments}

A typical competition experiment $(10 \mu \mathrm{L})$ employing KlenTaq DNA polymerase contained $1 \times$ KlenTaq reaction buffer, $150 \mathrm{~nm}{ }^{32} \mathrm{P}$-labelled primer, $200 \mathrm{~nm}$ template, $50 \mu \mathrm{M} \mathrm{dNTP} / \mathbf{d N}^{\mathrm{R}} \mathrm{TP}$ mixture, and $8 \mathrm{~nm}$ KlenTaq DNA polymerase. First primer and template were annealed. Afterwards the primer template complex, nucleotides and DNA polymerase were incubated $\left(55^{\circ} \mathrm{C} ; 30 \mathrm{~min}\right)$. The reactions were quenched by addition of $50 \mu \mathrm{L}$ PAGE gel loading buffer/stop solution and the product mixtures were analysed by $12 \%$ denaturing polyacrylamide gel and subjected to autoradiography. Quantification was done by using the Bio-Rad Quantity One software. The conversion in percent was plotted versus the concentration using the program ImageLab. All reactions were performed in triplicate.

\section{Gel electrophoresis}

Denaturing polyacrylamide gels $(12 \%)$ were prepared by polymerization of a solution of urea $(8.3 \mathrm{M})$ and bisacrylamide/acrylamide (12\%) in TBE buffer using ammonium peroxodisulfate (APS, $0.08 \%$ ) and $N, N, N^{\prime}, N^{\prime}$-tetramethylethylenediamine (TEMED, 0.04\%). Immediately after addition of APS and TEMED, the solution was filled in a sequencing gel chamber (Bio-Rad) and left for polymerization for at least $45 \mathrm{~min}$. After addition of TBE buffer $(1 \times)$ to the electrophoresis unit, gels were prewarmed by electrophoresis at $100 \mathrm{~W}$ for $30 \mathrm{~min}$ and samples were added and separated during electrophoresis $(100 \mathrm{~W})$ for ca. $1.5 \mathrm{~h}$. The gel was transferred to Whatman filter paper, dried at $80^{\circ} \mathrm{C}$ in vacuo with a gel dryer (model 583, Bio-Rad) and exposed to an imager screen. Readout was performed with a molecular imager (FX, Bio-Rad).

\section{Crystallisation, data collection and analysis}

Primer and template were purchased from MWG Eurofins. The protein was overexpressed and purified as described earlier ${ }^{[48]}$ and concentrated to $10 \mathrm{mg} \mathrm{mL}{ }^{1}$ for storage at $4{ }^{\circ} \mathrm{C}$. For crystallisation, a 2', $3^{\prime}$-dideoxy-cytidine terminated primer $\left(5^{\prime}\right.$-d(GAC CAC GGC GC)ddC) and a 16-mer template (5'-d(AAA A/TGG CGC CGT GGT C)) were used.

Primer/template construct was annealed and the ternary complex of KlenTaq was formed by mixing the protein (final concentration ca. $6.0 \mathrm{mg} \mathrm{mL}{ }^{1}$ in $20 \mathrm{~mm}$ Tris-HCl pH 7.5, $1 \mathrm{~mm}$ EDTA, $0.15 \mathrm{M} \mathrm{NaCl}$, $1 \mathrm{~mm} \beta$-mercaptoethanol), the primer/template DNA (final concentration ca. $0.120 \mathrm{~mm}$ ) and triphosphate $\mathbf{d N}^{\text {ene }} \mathrm{TP}$ in a molar ratio of 1:1.2:15 and the solution was set to a final concentration of $20 \mathrm{~mm}$ $\mathrm{MgCl}_{2}$. The mixture was incubated for $30 \mathrm{~min}$ at $30^{\circ} \mathrm{C}$. Crystals were grown in hanging drop plates (Qiagen) against $800 \mu \mathrm{L}$ reservoir (reservoir condition: $0.05 \mathrm{M}$ sodium cacodylate $\mathrm{pH} 6.5,0.01 \mathrm{M}$ $\mathrm{Mg}(\mathrm{OAc})_{2}, 0.2 \mathrm{M} \mathrm{NH}_{4} \mathrm{OAc}, 30 \%$ PEG 4000) in a 1:1 ratio protein/ DNA to reservoir. Crystals were harvested after six days of growth and dipped into a cryo-solution consisting of the crystallisation reservoir with additional $20 \%$ glycerol before freezing in liquid nitrogen.

Data were collected at the beamlines PXI and PXIII at the Swiss Light Source (SLS), Paul-Scherrer Institute, Villigen, Switzerland. Data reduction was performed with the XDS package. ${ }^{[49]}$ The structure was solved by difference Fourier techniques using KlenTaq wild-type (PDB 3M8S) ${ }^{[50]}$ as model. Refinement was performed with PHENIX ${ }^{[45]}$ and model rebuilding was done with COOT. $^{[51]}$ In both structures the complete enzyme (residues 293 832) and the primer/template duplex was modelled. Side chains without defined electron density were not deleted but modelled in a common rotamer conformation and high B-factors demonstrate their flexibility. The substrate nucleotide $\mathbf{d} \mathbf{A}^{\text {ene }} \mathbf{T P}$ was modelled in two conformations and refined with an occupancy of 0.5 for each conformation. The terminal alkyl chain of the linker in $\mathbf{d} \mathbf{U}^{\text {ene }} \mathbf{T P}$ as well as $\mathbf{d A ^ { \text { ene } }} \mathbf{T P}$ was not resolved in the electron density and was modelled in extension to the more rigid part (nucleotide plus linker until the amide functionality) and refined with zero occupancy. The restraints files (cif files) for the ligands were generated by using the grade webserver. ${ }^{[52]}$ Figures were made with PyMOL. ${ }^{[53]}$ Omit maps for the triphosphates are shown in Figure S2 and data collection and refinement statistics in Table S1. The atomic coordinates and structure factors have been deposited in the Protein Data Bank (www.rcsb.org) with PDB codes 5E41 for $\operatorname{KlenTaq}\left(\mathbf{d U}^{\text {ene }} \mathrm{TP}\right)$ and 5SZT for KlenTaq(dA $\left.{ }^{\text {ene }} T P\right)$.

\section{Acknowledgements}

We gratefully acknowledge financial support from the DFG and support and access to beamlines PXI and PXIII at the Swiss Light Source (SLS) of the Paul Scherrer Institute (PSI), Villigen, Switzerland.

Keywords: DNA replication - DNA structures - labelling DNA polymerase $\cdot$ nucleotides $\cdot$ structure elucidation

[1] D. R. Bentley, S. Balasubramanian, H. P. Swerdlow, G. P. Smith, J. Milton C. G. Brown, K. P. Hall, D. J. Evers, C. L. Barnes, H. R. Bignell, et al., Nature 2008, 456, 5359.

[2] E. R. Mardis, Annu. Rev. Genomics Hum. Genet. 2008, 9, 387402.

[3] G. Mayer, Angew. Chem. Int. Ed. 2009, 48, 2672 2689; Angew. Chem. 2009, 121, 27102727. 
[4] S. H. Weisbrod, A. Marx, Chem. Commun. 2008, 56755685.

[5] C. M. Perou, T. Sorlie, M. B. Eisen, M. van de Rijn, S. S. Jeffrey, C. A. Rees, J. R. Pollack, D. T. Ross, H. Johnsen, L. A. Akslen, Ø. Fluge, A. Pergamen schikov, C. Williams, S. X. Zhu, P. E. Lønning, A. L. Børresen Dale, P. O. Brown, D. Botstein, Nature 2000, 406, 747752.

[6] A. Baccaro, A. L. Steck, A. Marx, Angew. Chem. Int. Ed. 2012, 51, 254 257; Angew. Chem. 2012, 124, 260263.

[7] M. Hocek, M. Fojta, Org. Biomol. Chem. 2008, 6, 22332241.

[8] M. Hollenstein, Molecules 2012, 17, 1356913591.

[9] O. Thum, S. Jäger, M. Famulok, Angew. Chem. Int. Ed. 2001, 40, 3990 3993; Angew. Chem. 2001, 113, 41124115.

[10] T. Ohbayashi, M. Kuwahara, M. Hasegawa, T. Kasamatsu, T. Tamura, H. Sawai, Org. Biomol. Chem. 2005, 3, 24632468.

[11] S. Jäger, G. Rasched, H. Kornreich Leshem, M. Engeser, O. Thum, M. Fa mulok, J. Am. Chem. Soc. 2005, 127, 1507115082.

[12] M. Kuwahara, J. i. Nagashima, M. Hasegawa, T. Tamura, R. Kitagata, K. Hanawa, S. i. Hososhima, T. Kasamatsu, H. Ozaki, H. Sawai, Nucleic Acids Res. 2006, 34, 53835394.

[13] M. Hocek, J. Org. Chem. 2014, 79, 99149921.

[14] J. Sági, A. Szemzö, K. Ébinger, A. Szabolcs, G. Sági, É. Ruff, L. Ötvös, Tet rahedron Lett. 1993, 34, 21912194.

[15] B. M. Znosko, T. W. Barnes, T. R. Krugh, D. H. Turner, J. Am. Chem. Soc. 2003, 125, 60906097.

[16] F. Seela, E. Feiling, J. Gross, F. Hillenkamp, N. Ramzaeva, H. Rosemeyer, M. Zulauf, J. Biotechnol. 2001, 86, 269279.

[17] L. H. Thoresen, G. S. Jiao, W. C. Haaland, M. L. Metzker, K. Burgess, Chem. Eur. J. 2003, 9, 46034610.

[18] D. Verga, M. Welter, A. L. Steck, A. Marx, Chem. Commun. 2015, 51, 73797381.

[19] D. Cherkasov, T. Biet, E. Bäuml, W. Traut, M. Lohoff, Bioconjugate Chem. 2010, 21, 122129.

[20] Z. Zhu, J. Chao, H. Yu, A. Waggoner, Nucleic Acids Res. 1994, 22, 3418 3422.

[21] C. J. Lacenere, N. K. Garg, B. M. Stoltz, S. R. Quake, Nucleosides Nucleo tides Nucleic Acids 2006, 25, 915.

[22] M. Welter, D. Verga, A. Marx, Angew. Chem. Int. Ed. 2016, 55, 10131 10135; Angew. Chem. 2016, 128, 1028610290.

[23] T. Tasara, Nucleic Acids Res. 2003, 31, 26362646.

[24] G. Giller, T. Tasara, B. Angerer, K. Mühlegger, M. Amacker, H. Winter, Nu cleic Acids Res. 2003, 31, 26302635

[25] S. E. Lee, Nucleic Acids Res. 2001, 29, 15651573.

[26] J. P. Anderson, B. Angerer, L. A. Loeb, Biotechniques 2005, 38, 257264.

[27] P. Kielkowski, J. Fanfrlík, M. Hocek, Angew. Chem. Int. Ed. 2014, 53, 7552 7555; Angew. Chem. 2014, 126, 76827685.

[28] K. Bergen, A. L. Steck, S. Strütt, A. Baccaro, W. Welte, K. Diederichs, A. Marx, J. Am. Chem. Soc. 2012, 134, 1184011843.

[29] H. Cahová, A. Panattoni, P. Kielkowski, J. Fanfrlík, M. Hocek, ACS Chem. Biol. 2016, 11, 31653171.

[30] A. Hottin, A. Marx, Acc. Chem. Res. 2016, 49, 418427.

[31] S. Obeid, H. Bußkamp, W. Welte, K. Diederichs, A. Marx, Chem. Commun. 2012, 48, 8320 .

[32] S. Obeid, H. Bußkamp, W. Welte, K. Diederichs, A. Marx, J. Am. Chem. Soc. 2013, 135, 1566715669.
[33] S. Obeid, A. Baccaro, W. Welte, K. Diederichs, A. Marx, Proc. Natl. Acad. Sci. USA 2010, 107, 2132721331.

[34] K. Sakthivel, C. F. Barbas III, Angew. Chem. Int. Ed. 1998, 37, 2872 2875; Angew. Chem. 1998, 110, 29983002.

[35] T. Gourlain, Nucleic Acids Res. 2001, 29, 18981905.

[36] J. Dadová, P. Vidláková, R. Pohl, L. Havran, M. Fojta, M. Hocek, J. Org. Chem. 2013, 78, 96279637.

[37] C. C. C. Johansson Seechurn, M. O. Kitching, T. J. Colacot, V. Snieckus, Angew. Chem. Int. Ed. 2012, 51, 5062 5085; Angew. Chem. 2012, 124, 51505174.

[38] M. Yoshikawa, T. Kato, T. Takenishi, Tetrahedron Lett. 1967, 8, 5065 5068.

[39] P. Espinet, A. M. Echavarren, Angew. Chem. Int. Ed. 2004, 43, 4704 4734; Angew. Chem. 2004, 116, 48084839.

[40] S. J. Connon, S. Blechert, Angew. Chem. Int. Ed. 2003, 42, 1900 1923; Angew. Chem. 2003, 115, 19441968.

[41] R. H. Grubbs, Angew. Chem. Int. Ed. 2006, 45, 3760 3765; Angew. Chem. 2006, 118, 38453850.

[42] J. G. Bertram, K. Oertell, J. Petruska, M. F. Goodman, Biochemistry 2010 49, 2028.

[43] Y. Li, V. Mitaxov, G. Waksman, Proc. Natl. Acad. Sci. USA 1999, 96, 9491 9496.

[44] K. Betz, D. A. Malyshev, T. Lavergne, W. Welte, K. Diederichs, T. J. Dwyer, P. Ordoukhanian, F. E. Romesberg, A. Marx, Nat. Chem. Biol. 2012, 8, 612614.

[45] P. D. Adams, P. V. Afonine, G. Bunkoczi, V. B. Chen, I. W. Davis, N. Echols, J. J. Headd, L. W. Hung, G. J. Kapral, R. W. Grosse Kunstleve, A. J. McCoy, N. W. Moriarty, R. D. Oeffner, R. J. Read, D. C. Richardson, J. S. Richard son, T. C. Terwilliger, P. H. Zwart, Acta. Crystallogr. Sect. D 2010, 66, 213 221.

[46] A. V. Lebedev, D. Combs, R. I. Hogrefe, Bioconjugate Chem. 2007, 18, 15301536.

[47] J. F. Teichert, M. Fañanás Mastral, B. L. Feringa, Angew. Chem. Int. Ed. 2011, 50, 688 691; Angew. Chem. 2011, 123, 714717.

[48] K. Betz, D. A. Malyshev, T. Lavergne, W. Welte, K. Diederichs, F. E. Romes berg, A. Marx, J. Am. Chem. Soc. 2013, 135, 1863718643.

[49] W. Kabsch, Acta. Crystallogr. Sect. D 2010, 66, 125132.

[50] K. Betz, F. Streckenbach, A. Schnur, T. Exner, W. Welte, K. Diederichs, A. Marx, Angew. Chem. Int. Ed. 2010, 49, 5181 5184; Angew. Chem. 2010, $122,53085311$.

[51] P. Emsley, B. Lohkamp, W. G. Scott, K. Cowtan, Acta Crystallogr. Sect. D 2010, 66, 486501.

[52] O. S. Smart, T. O. Womack, A. Sharff, C. Flensburg, P. Keller, W. Paciorek, C. Vonrhein, G. Bricogne, grade, version 1.2.9, http://www.globalpha sing.com, 2011.

[53] Schrödinger, LLC, The PyMOL Molecular Graphics System, Version 1.7.6, 2015. 